\title{
Hard Times for Unions: Another Look at the Significance of Employer Illegalities
}

\author{
Robert J. LaLonde $\dagger$ and Bernard D. Meltzer $\dagger$
}

It is well known that the percentage of American workers in the private sector belonging to labor unions ("union density") has declined sharply in the last four decades. ${ }^{1}$ From 1953 to 1989 , density fell from 35 percent to 12 percent, ${ }^{2}$ and the absolute number of union members in the private sector shrank from more than 14.8

$\dagger$ Associate Professor, Graduate School of Business, The University of Chicago.

if Distinguished Service Professor of Law, Emeritus, The University of Chicago. We received valuable comments on an earlier draft from Norton J. Come, Robert J. Flanagan, Stephen B. Goldberg, Deborah Hensler, Morris Kleiner, William H. Kruskal, Edward B. Miller, Alan O. Sykes, Leo Troy, and participants in The University of Chicago's Labor Workshop. For helping us to obtain NLRB data and improving our perspective on the NLRB's operations, we are indebted to Donald J. Crawford, formerly Regional Director of the NLRB's office in Chicago, and John C. Truesdale, Executive Secretary of the NLRB.

The following students helped at various times with research, manuscript checking, and thoughtful suggestions: Tom Eron (a fellow in the Illinois Bar Foundation's Research Fellow Program, which provided partial research support), Mark Jones, Gerald Marschke, Craig Rosenbaum, Robin Schulberg, and Tom Vega-Byrnes. The University of Chicago Graduate School of Business and Law School provided research support.

1 Union density refers to the percentage of employees in the labor force who belong to unions. Plainly, union density in a particular industry must be distinguished from the growth or decline in membership there. Such density may decline while membership increases because of an overall increase in employment. Thus, between 1953 and 1973 the number of private sector union members increased by more than one million, but union density declined by nine percentage points. See Leo Troy, The Rise and Fall of American Trade Unions: The Labor Movement from FDR to RR, in Seymour M. Lipset, ed, Unions in Transition 75, 82, Table 3 (ICS, 1986).

Statistics on changes over time in union membership and density are derived from several different sources. Consequently, statistics on union membership in widely separated years are usually not comparable. The pertinent problems are summarized in Leo Troy and Neil Sheflin, U.S. Union Sourcebook: Membership, Finances, Structure, Directory 3-2, 3-3 (IRDIS, 1985). See also Statistical Appendix, Section I for a discussion of the adjustments designed to make statistics on union membership and union densities for different periods comparable.

? See 42 Current Wage Developments 7, Table 2 (Bureau of Labor Statistics, Feb 1990). 
million in 1953 to 10.5 million in $1989 . .^{3}$ Such declines have, of course, occurred throughout our history. ${ }^{4}$ As Selig Perlman observed in 1928, "[t]he overshadowing problem of the American labor movement [has been] the problem of staying organized."

The recent decline is, however, distinctive because it occurred within the ostensibly protective legal environment created by the National Labor Relations Act of 1935 (the Wagner Act), as amended. ${ }^{6}$ An extensive literature has sought to identify and rank the causes of this decline. Much of this literature attributes it principally to social and economic developments that are largely beyond the short-term control of particular unions or firms. ${ }^{7}$

In a celebrated article, Professor Paul Weiler recognized that these larger forces have shaped individual workers' decisions about unionization. ${ }^{8}$ Nonetheless, he identified increased employer opposition and, especially, unlawful opposition, together with anemic and dilatory statutory remedies, as major factors in the decline of private sector unionism. We will call this emphasis the "rogue employer thesis." Specifically, Professor Weiler pointed to an increase in two types of employer violations: discharges of union supporters during organizational campaigns, ${ }^{9}$ and employers' refusal to bar-

${ }^{3}$ Troy and Sheflin, U.S. Union Sourcebook 3-14, Table 3.62 (cited in note 1); see Statistical Appendix, Section I.

- For example, the membership of American and Canadian unions declined from 5 million in 1920 to 3.4 million in 1929. See Leo Wolman, Ebb and Flow in Trade Unionism 16, Table 5 (National Bureau of Economic Research, 1936); Irving Bernstein, A History of the American Worker-1920-1933: The Lean Years 203 (Penguin, 1960); Leo Wolman, The Growth of American Trade Unions, 1880-1923 31-32 (National Bureau of Economic Research, 1924).

- Selig Perlman, A Theory of the Labor Movement 162 (Augustus M. Kelley, 1949).

B 29 USC $\S \S 151-169$ (1988). For a summary of various provisions of the Act as amended, see text at notes $16,40-44,63,66,73,83,91,96,109,110$.

' See Bernard D. Meltzer, Is the NLRB a Closed Shop to Labor?, Wall St J 34 (Oct 18, 1984); Henry S. Farber, The Recent Decline of Unionization in the United States, 238 Science 915, 916-18 (1987); Troy, The Rise and Fall of American Trade Unions, in Lipset, ed, Unions in Transition at 94-103 (cited in note 1); Seymour M. Lipset, North American Labor Movements: A Comparative Perspective, in id, 442, 445-47, 459 (stressing the signifcance of shifts in attitudes from class-conscious, anti-corporate, statist values to traditional, individualistic, and free-market values). For further development of that thesis, see Seymour M. Lipset, Labor and Socialism in Canada and the United States, Larry Sefton Memorial Lecture, University of Toronto, Wordsworth College (Mar 8, 1990). Farber, however, highlights increased employer resistance, as measured by increased unfair labor practice charges per election, and suggests that increased employer resistance, legal and illegal, has resulted signficantly from foreign competition. Science at 919-20.

${ }^{8}$ Paul Weiler, Promises to Keep: Securing Workers' Rights to Self-Organization under the NLRA, 96 Harv L Rev 1769, 1772-73 (1983).

- See, for example, id at 1772-74, 1781. 
gain in good faith with newly certified unions. ${ }^{10}$ Indeed, he estimated that one in twenty pro-union voters in elections conducted by the National Labor Relations Board had been discriminatorily discharged. ${ }^{11}$ Relying on these findings, he proposed significant changes in the timing of NLRB representation elections, ${ }^{12}$ in the remedies for "egregious" failures to bargain in good faith with a newly certified union, ${ }^{13}$ and in the type of economic pressures permitted to employers and unions faced with a bargaining impasse. ${ }^{14}$

Others have already questioned whether employer illegalities have been a major factor in the decline of American unions. ${ }^{15} \mathrm{We}$ explore that question in light of both legal and empirical considerations that have frequently been neglected. The legal considerations include the following: the extent to which the NLRA provides the basis for large backpay awards and reinstatement offers in situations far removed from the organizational context, the doctrinal and legislative changes that have created new grounds or new incentives for filing unfair labor practice charges against employers, and the expansion of the NLRB's jurisdiction by changes in Board rules and by legislation.

The empirical considerations flow from our examination of Board decisions in 1955 and 1980 and case-handling by the Chicago regional office in 1985 and 1986. Through these and related inquiries, we hope to cast some light on the incidence of employer illegalities, particularly unlawful discharges during organizational campaigns or first-contract negotiations, as distinguished from illegalities that occur during later stages of an employment relation-

10 Paul Weiler, Striking a New Balance: Freedom of Contract and the Prospects for Union Representation, $98 \mathrm{Harv} \mathrm{L}$ Rev 351, 354-56 (1984). He has also referred to weakness in the administration of the NLRA. Id at 360-61.

11 Weiler, 96 Harv L Rev at 1781 (cited in note 8).

12 In order to limit an employer's opportunity for pre-election coercion, Weiler proposed "instant elections" to take place a few days after a union filed an election petition. Id at 1812-16 (cited in note 8).

${ }^{13}$ In order to remedy such failure, an arbitrator would write the parties' agreement. Weiler, 98 Harv L Rev at 405 (cited in note 10).

14 In order to increase union bargaining leverage and legal protection, employers would be barred from permanently replacing strikers, id at 387-94, and some of the prohibitions against secondary boycotts by unions would be lifted, id at 415-19. Weiler, in Governing the Workplace: The Future of Labor and Employment Law (Harvard, 1990), which reached us long after we had submitted this article to the Law Review, repeats, reshapes, and supplements various policy proposals set forth in his articles cited here. See notes 8,10 . The merits of those proposals are beyond the scope of this Article. Our primary purposes are to assess empirical findings that bear on the formulation and appraisal of such proposals and to suggest changes in the Board's reporting of data about its operations that, in the longer term at least, may facilitate more informed policy formulation.

18 See sources cited in note 7 . 
ship. Our empirical findings suggest that estimates of both the losses of employment linked to organizational campaigns and the frequency with which employers violate their duty to bargain in relation to newly certified unions have been too high. ${ }^{16}$

We proceed as follows. Part I describes the factors in the decline in union density, particularly the potential role of employer illegalities. Part II briefly treats legislative and doctrinal changes that have enlarged the Board's effective jurisdiction, created new grounds for substantial backpay awards, and provided organizational benefits to unions from filing charges (including unmeritorious ones) against employers alleging violations of the Act. Part III presents the results of our study of decisions by the Board and settlements by its Chicago regional office. Part IV reassesses the contention that employer misconduct has been a major factor in union decline. Finally, Part V suggests ways in which the NLRB could change its rubrics for describing its docket-changes that would probably make the data contained in the Board's annual reports more useful to students of industrial relations, and especially to those seeking to understand the connections among various kinds of employer unfair labor practices and the organizational failures of unions.

\section{The Decline in Private Sector Unionization}

\section{A. The Effects of Changes in Employment Composition}

Economic and cultural factors independent of employer illegalities explain much of American deunionization since the 1950s. Some goods-producing industries-the traditional strongholds of the union movement-have suffered substantial declines in employment. The steel and automobile industries are striking illustrations. The goods-producing industries as a whole have also suffered a decline in employment relative to that of the services industries, which traditionally have been less unionized. ${ }^{17}$ Several interrelated factors have contributed to these structural changes, including a

16 Other employer violations during organizational campaigns, such as coercive speech or unlawful benefits, may also frustrate union organizational efforts. Our principal concern here is, however, with discriminatory discharges during organizational campaigns and with employer refusals to recognize, or to bargain in good faith with, a newly certified union.

17 See Troy and Sheflin, U.S. Union Sourcebook at 3-16 (cited in note 1) (indicating how changes in union membership reflect the declining share of employment in goods-producing industries. See also U.S. Dept. of Labor, 36:4 Employment and Earnings 77, Table B-1 (Apr 1989); U.S. Dept. of Labor, 112:4 Monthly Labor Review 67, Table 13 (Apr 1989). 
shift of consumer demand from goods to services; ${ }^{18}$ a relative increase in the number of professional, managerial, and other white collar workers; ${ }^{19}$ faster growth in labor productivity in manufacturing than in other sectors; ${ }^{20}$ and increased import competition. ${ }^{21}$ The effects of these structural changes appear to have been compounded by employment shifts from the northeast and midwest to the sun belt, where the political environment has traditionally been less receptive to unionization. ${ }^{22}$ In addition, deregulation in various industries was followed by a reduction in union densities. ${ }^{23}$

It is difficult to isolate and estimate the effects of structural factors on union density in the United States. Structural changes have interacted with other factors, such as the apparent increase in employer opposition to unionization, ${ }^{24}$ the apparent reduction in union organizing activity, ${ }^{25}$ the reduction in public approval of unions as reflected in public opinion polls, ${ }^{26}$ and the increase in employee opposition to unionization. ${ }^{27}$ These variables are neither in-

18 The share of total real consumption expenditures represented by services rose from 40.2 percent in 1953 to 46.6 percent in 1988. See Economic Report of the President 1989 317, Table B-7 (GPO, 1989).

10 See Lawrence F. Katz and Ana L. Revenga, Changes in the Structure of Wages: The U.S. us. Japan 22, Table 7 (National Bureau of Economic Research Working Paper, 1989) (on file with U Chi L Rev). For an exposition of the considerations that have made "white collars" (a manifestly loose grouping) more difficult to organize, see Charles C. Heckscher, The New Unionism 64-71, 259 n 36 (Basic, 1988). See also Thomas Kochan, Collective Bargaining and Industrial Relations 147 (Richard D. Irwin, 1980), rejecting the contention that white collar workers (except for administrators and professionals) are more reluctant to organize than other groups when faced with similar working conditions.

${ }^{20}$ See U.S. Dept. of Labor, 112:5 Monthly Labor Review 107, Table 44 (May 1989).

${ }^{21}$ See John M. Abowd and Thomas Lemieux, The Effects of International Competition on Collective Bargaining Outcomes: A Comparison of the United States and Canada (National Bureau of Economic Research Working Paper, 1990) (on file with U Chi L Rev).

${ }^{22}$ See Barry T. Hirsch and John T. Addison, The Economics of Unions: New Approaches And Evidence 63-64 (Allen and Unwen, 1986).

${ }^{23}$ See Nancy Rose, Labor Rent Sharing and Regulation: Evidence from the Trucking Industry, $95 \mathrm{~J}$ Pol Econ 1146 (1987).

${ }^{24}$ See Richard Freeman, Contraction and Expansion: The Divergence of Private Sector and Public Sector Unionism in the United States, $2 \mathrm{~J}$ Econ Persp 63, 77, 82, 86 (1988).

${ }^{25}$ See Richard Freeman, Why are Unions Faring Poorly in NLRB Representation Elections, in Thomas A. Kochan, ed, Challenges and Choices Facing American Labor Law 45 (MIT, 1985).

26 See Seymour M. Lipset, North American Labor Movements: A Comparative Perspective, in Lipset, ed, Unions in Transition 421, 438 (cited in note 1); James L. Medoff, The Public's Image of Labor and Labor's Response, 3 Detroit Coll L Rev 609-23 (1987). Compare Melvin W. Reder, The Rise and Fall of Unions: The Public Sector and Private, 2 J Econ Persp 89, 101 (1986) (opinion polls of uncertain significance because worker disapproval of unions might result from anticipation of successful employer resistance rather than from hostility to union methods or objectives per se).

${ }^{27}$ See Leo Troy, Will a More Interventionist NLRA Revive Organized Labor?, 13 Harv J L \& Pub Pol 583, 595-601 (1990) (employee opposition is of crucial importance to union 
dependent nor mutually exclusive. Indeed, they often reenforce each other. ${ }^{28}$

It is not necessary here to explore competing assessments of the relative significance of structural and other factors for American deunionization. Instead, we merely note that there is substantial support in the literature for the position that structural and related changes (even though they are key factors) fail to explain a significant amount of deunionization. ${ }^{29}$ Consequently, more attention has been focused on the importance of increased employer opposition, legal and illegal, for American deunionization.

\section{B. Declining Union Election Successes}

Employer opposition has been associated with another cause of union decline-the sharp reduction in the number of workers organized through NLRB elections, the most common route to representation..$^{30}$ As Table 1 shows, during the early 1950 s, the total number of employees in units voting for union representation in NLRB elections averaged 554,100 per year. Table 1 also shows that in the $1950 \mathrm{~s}$, unions organized approximately 1.3 percent of the private nonagricultural workforce annually through NLRB elections. ${ }^{31}$ Given the sharp increase in that workforce in the years that followed, equivalent success for unions today would require them annually to win elections in units totaling 1.1 million workers. ${ }^{32}$ Instead, during the late 1980 s, the total number of employees

decline and makes employer opposition essentially irrelevant).

${ }^{28}$ See Farber, 238 Science at 915 (cited in note 7).

${ }^{29}$ See Freeman, $2 \mathrm{~J}$ Econ Persp at 76 (cited in note 24).

${ }^{30}$ American unions generally achieve representation in one of three ways: NLRB elections; Board unfair labor practice orders; or voluntary recognition by employers. See Philip Ross, The Labor Law in Action: An Analysis of the Administrative Process under the TaftHartley Act 12, Report to NLRB Chairman McCulloch (1966).

${ }^{31}$ This figure encompasses all workers (not merely union members or union supporters) employed in bargaining units in which unions secured representation rights through an NLRB election. The number of such workers who are union members is less than this figure, for two reasons. First, not all workers in such units join the union. Second, a union winning an election frequently is unable to negotiate a collective bargaining agreement; consequently, its membership base erodes.

We derived the percentages in Table 1, column 2, from the number of employees in units in which a union secured a majority vote divided by the number of employees in the private nonagricultural workforce. See 15-53 NLRB Annual Reports (1950-88); Economic Report of the President 1990 342-43, Table C-43 (GPO, 1989). See also Freeman, 2 J Econ Persp at 74 (cited in note 24 ).

${ }^{32}$ This figure is derived by multiplying average private nonagricultural employment in 1988 (88.2 million) by .013, the fraction of such employment in units voting for union representation in the 1950s. See Economic Report of the President 1990 at 342-43, Table C-43 (cited in note 31 ). 
in such units declined sharply, to 80,300 per year or roughly 0.1 percent of the private nonagricultural workforce. ${ }^{33}$

TABLE 1

\section{DECLINING UNION SUCCESS IN NLRB ELECTIONS [Annual Averages During Period]}

\begin{tabular}{cccccc} 
Years & $\begin{array}{c}\text { Newly } \\
\text { Represented } \\
\text { Employees }\end{array}$ & $\begin{array}{c}\text { Share of } \\
\text { Work Force }\end{array}$ & $\begin{array}{c}\text { Number of } \\
\text { Elections }\end{array}$ & $\begin{array}{c}\text { Size of } \\
\text { Unit }\end{array}$ & $\begin{array}{c}\text { Union } \\
\text { Win Rate }\end{array}$ \\
\hline $1950-54$ & 554,100 & $1.3 \%$ & 5906 & 121 & $72 \%$ \\
$1955-59$ & 277,700 & 0.6 & 4731 & 94 & 64 \\
$1960-64$ & 274,800 & 0.6 & 6854 & 73 & 58 \\
$1965-69$ & 315,800 & 0.6 & 7776 & 73 & 59 \\
$1970-74$ & 254,400 & 0.4 & 8298 & 67 & 54 \\
$1975-79$ & 185,000 & 0.3 & 7884 & 63 & 49 \\
$1980-84$ & 115,500 & 0.2 & 5048 & 60 & 46 \\
$1985-88$ & 80,300 & 0.1 & 3558 & 60 & 48 \\
\hline
\end{tabular}

Notes: "Newly Represented Employees" refers to the number of eligible voters in units in which a union secured a majority in collective bargaining ("RC" or "RM") elections. "Share of Work Force" refers to the number of newly represented employees stated as a percentage of the private nonagricultural work force. "Number of Elections" refers to the number of collective bargaining elections. "Size of Unit" refers to the average number of eligible voters in units holding collective bargaining elections. "Union Win Rate" refers to percentage of collective bargaining elections won by unions. Sources: 15-53 NLRB Annual Reports (1950-88); Economic Report of the President 1990 342-43, Table C-43 (GPO, 1989).

This decline reflects the combined effects of reductions in the number of elections held, in the average size of electoral units, and in unions' success rates. Thus, Table 1 reveals the following. First, the decline in numbers of newly organized workers from the 1950s to the 1980s resulted principally from both a 24-point drop in the percentage of elections won by unions and a substantial decline in the average size of electoral units. Second, the decline in the number of newly organized workers since the late 1970s resulted principally from a decrease in the number of elections and, to a much

\footnotetext{
ss The declining number of newly organized workers appears to account for a modest portion of the decline in union densities. Dickens and Leonard suggest that the decline in union victory rates accounts for seven percentage points of that decline since the 1950s. William T. Dickens and Jonathan S. Leonard, Accounting for the Decline in Union Membership, 1950-1980, 38:3 Industrial \& Labor Rel Rev 323, 332 (1985). Bronars and Deere found that between 1973 and 1988, the decline in the number of employees in the units in which unions secured representation rights accounted for 13 percent of the 13.7 percentage point decline in the private sector union density. Stephen G. Bronars and Donald R. Deere, Union Membership, Union Oganizing Activity, and the Union Wage Differential 1973-1988 (unpublished working paper, Oct 1990) (on file with U Chi L Rev).
} 
lesser extent, from a continued decrease in either union victory rates or the average size of election units. ${ }^{34}$

The smaller average size of election units is at least partially associated with structural changes in the U.S. economy. The increasing share of employment in the service-producing industries presumably meant that unions were increasingly faced with organizing smaller firms in these traditionally unorganized industries. ${ }^{35}$ Furthermore, industries in which unions had traditionally flourished presented similar problems. Thus, because of the increase in the fraction of midsize firms relative to large establishments in capital-intensive industries, elections were more likely to be held in smaller units even in such industries. ${ }^{36}$ In manufacturing, for example, the average size of election units, fell from 133 employees in 1955 to 79 in $1988^{37}$

The declining union success rates are not, however, directly explicable by structural changes in the economy. As Table 1 shows, the largest decline in those rates occurred between the 1950s and 1960 s, rather than between the 1970s and 1980s, when structural changes were having their greatest effect. In addition, as Table 2 shows, union success rates have fallen sharply even in traditionally organized industries. In manufacturing, where most NLRB elections occurred, unions had a success rate of only 40 percent in the 1980s compared with 69 percent in the 1950s. Thus, the overall decline in union success rates in NLRB elections can be attributed

34 Between the 1950s and the 1970s, the number of NLRB elections per year rose by 60 percent. This increase somewhat offsets the effects of both the declining union win rates and the declining average size of electoral units. In the 1980s, the union success rate and the average size of electoral units declined slightly, while the number of NLRB elections dropped by more than one-half. It is unclear whether the reduced number of elections reflected a reduction in investments in organizing activity, an increase in average costs associated with organizing smaller units, or greater difficulty in securing the support that is a prerequisite for an NLRB election.

${ }_{35}$ Smaller units did not necessarily contribute to the decline in union organizing success. During the 1980 s, union victory rates in units with fewer than 20 employees were 20 percentage points higher than in units with between 100 and 1,000 employees. See 45-53 NLRB Annual Reports Table 17 (1980-88). Similarly, in collective bargaining elections held between July 1972 and June 1977, the union win rate declined as the size of the unit increased. See cases closed between July 1972 and June 1977, NLRB Representation Election Database (NLRB Management and Information Systems Branch).

${ }^{36}$ See Steve J. Davis and John Haltiwanger, The Distribution of Employees by Establishment Size in the U.S. (unpublished working paper, 1989) (on file with U Chi L Rev).

${ }^{37}$ In 1980, a year highlighted in Professor Weiler's study, the average size of manufacturing election units was 84 employees. See 20 NLRB Annual Report 176, Table 17 (1955); 45 NLRB Annual Report 284, Table 16 (1980); 53 NLRB Annual Report 236, Table 16 (1988). 
TABLE 2

UNION VICTORIES IN ELECTIONS [Average Annual Percentage Won By Unions]

Industry 1950-59

1980-88

Mining

Construction

$71 \%$

$39 \%$

Manufacturing

78

69

47

Transportation/Communications/

Public Utilities

71

63

40

Wholesale/Retail Trade

Finance, Insurance, Real Estate/

Personal and Business Services

73

46

Total Private Sector

68

43

Notes: The columns in the table report for each industry the percentage of NLRB elections won by unions. The figures include both collective bargaining and decertification elections. Source: 15-24, 45-53 NLRB Annual Reports Table 18 (1950-59), Table 16 (1980-88).

principally to union election failures in the traditionally organized sectors of the economy. ${ }^{38}$

C. Increasing Litigation and Employer Lawlessness

While union election successes declined, the number of unfair labor practice (ULP) charges against employers surged. As shown by Table 3 , during the early 1950 s, when union victory rates were at their peak, unions and employees annually filed an average of 4,344 ULP charges against employers. By contrast, during the early 1980s, when union win rates were at a low, charges filed against employers soared to an annual average of nearly 30,000 .

An extensive literature concludes that a causal connection exists between that increase in ULP charges and unions' declining success rates in NLRB elections. ${ }^{30}$ That conclusion rests on two

38 In 1988, 60 percent of NLRB elections occurred in traditionally organized sectors: mining, construction, manufacturing, transportation, communications, and public utilities. 53 NLRB Annual Report 236-37, Table 16 (1988). In that year, those sectors employed only 35 percent of the private nonagricultural work force and an even smaller percentage of the unorganized work force. See Economic Report of the President 1990 at 342-3, Table C-43 (cited in note 31 ).

30 See Richard B. Freeman and James L. Medoff, What Do Unions Do?, 230-45 (Basic, 1984); Freeman, $2 \mathrm{~J}$ Econ Persp at 79 (cited in note 24); Weiler, 96 Harv L Rev at 1769 (cited in note 8); Weiler, 98 Harv L Rev at 351 (cited in note 10); see also The Failure of Labor Law-A Betrayal of American Workers, Report of Subcommittee on Labor-Management Relations, House Committee on Education and Labor, 98th Cong, 2d Sess (1984), reprinted in Leroy Merrifield, Theodore St. Antoine, and Charles Craver, Labor Relations Law: Cases and Materials 57-58 (Michie, 8th ed 1989). 


\section{TABLE 3}

\section{UNFAIR LABOR PRACTICE CHARGES REMEDIES, AND UNION ELECTION-WIN RATES [Annual Averages for 5-Year Periods]}

\begin{tabular}{lrrrrrrr} 
Years & $\begin{array}{c}\text { Total } \\
\text { Charges }\end{array}$ & $\begin{array}{c}8(a)(3) \\
\text { Charges }\end{array}$ & $\begin{array}{c}\text { 8(a)(5) } \\
\text { Charges }\end{array}$ & $\begin{array}{c}\text { Back Pay in } \\
1988 \text { Dollars } \\
(1,000 \text { s })\end{array}$ & $\begin{array}{c}\text { Employees } \\
\text { Offered } \\
\text { Reinstatement }\end{array}$ & $\begin{array}{c}\text { Bargaining } \\
\text { Begun or } \\
\text { Resumed }\end{array}$ & $\begin{array}{c}\text { Union } \\
\text { Win Rate } \\
\text { in Elections }\end{array}$ \\
\hline $1950-54$ & 4,344 & 3,035 & 1,266 & $\$ 6,193$ & 2,194 & 234 & $72 \%$ \\
$1955-59$ & 5,175 & 3,993 & 1,046 & 3,474 & 9,437 & 119 & 64 \\
$1960-64$ & 9,067 & 6,746 & 2,279 & 7,563 & 2,876 & 485 & 58 \\
$1965-69$ & 11,401 & 7,657 & 3,902 & 15,682 & 4,638 & 1,204 & 59 \\
$1970-74$ & 16,428 & 10,684 & 5,306 & 14,727 & 4,317 & 1,520 & 54 \\
$1975-79$ & 25,213 & 15,912 & 7,420 & 25,832 & 4,817 & 1,726 & 49 \\
$1980-84$ & 28,830 & 15,736 & 10,628 & 41,984 & 6,844 & 2,107 & 46 \\
$1985-88$ & 22,843 & 11,821 & 9,644 & 38,248 & 5,647 & 2,597 & 48 \\
\hline
\end{tabular}

Notes: See Table 1 for a definition of "Union Win Rate." "Total Charges," "8(a)(3) Charges," and " $8(a)(5)$ Charges" are average number of unfair labor practice allegations filed against employers annually. 15-53 NLRB Annual Reports Table 3 (1950), Table 2 (1951-88). "Back Pay" refers to awards to employees in thousands of 1988 dollars as a result of a Board order or settlement between the parties under the aegis of the Board. "Employees Offered Reinstatement" refers to number of employees offered reinstatement as a result of a Board order or settlement. "Bargaining Begun or Resumed" refers to number of times an employer begins or resumes collective bargaining as a result of a Board order or settlement. In 1959, 41,200 employees were offered reinstatement. Excluding that unusual year from the tables reduces the average number of persons offered reinstatement annually between 1955 and 1959 from 9,437 to 1,496. 15-53 NLRB Annual Reports Table 4 (1950-88).

interrelated contentions. First, after the mid-1950s, employers had stronger incentives to use borderline or flatly illegal tactics in their anti-union campaigns. Second, increased resort to such tactics not only led to the surge in ULP charges but also frustrated or discouraged union organizing efforts and contributed significantly to the decline of unions.

As background for assessing these contentions, we offer a greatly oversimplified description of the protections provided by the NLRA, as amended. ${ }^{40}$ The NLRA establishes the right of employees to join, or refrain from joining, unions. It also proscribes "interference" with, or "discrimination" because of, the exercise of those rights. ${ }^{41}$ The NLRA also provides for machinery that enables employees to vote by secret ballot on whether they want union representation. ${ }^{42}$ In administering that machinery, the NLRB defines an "appropriate" unit for bargaining and monitors employer and

4029 USC $\S \S 151-169$ (1988).

429 USC $\S \S 151,157,158$ (a).

42 "Collective bargaining elections" generally involve voting by unrepresented employees on whether they want union representation; in "decertification elections" employees vote on the retention of an incumbent union. See 53 NLRB Annual Report 182 (1988); 29 USC § 159(e). 
union conduct both before and during elections. ${ }^{43}$ Finally, § 8(a)(5) requires an employer to bargain in "good faith" with a union that represents a majority of its employees in an appropriate unit. ${ }^{44}$

Commentators have stressed the Act's increasing ineffectiveness in deterring discriminatory discharges, in protecting employee free choice, and in enforcing an employer's duty to bargain with a certified union. ${ }^{45}$ For supporting evidence, they have pointed to the increase in the number of employees awarded backpay or offered reinstatement. As Table 3 shows, from the 1950s to the 1980s, the amount of backpay awarded annually increased ninefold (even after adjusting for inflation). The increase in the number of employees covered by reinstatement offers, although less dramatic, is substantial. ${ }^{46}$ Finally, the instances in which employers began or resumed collective bargaining because of a Board order or a settlement (reached under its aegis) increased more than tenfold between the 1950s and the 1980s.

Proponents of the rogue employer thesis attribute the apparent surge in violations to several features of the regulatory machinery. First, there is the notorious delay between the filing of a "meritorious charge" (that is, one that warrants the issuance of a complaint by the NLRB General Counsel) and a Board decision. For fiscal year 1988, the median interval between the filing of charges and Board adjudication was 762 days. ${ }^{47}$ Furthermore, prior to judicial enforcement, there are no sanctions for noncompliance with a Board order based on a finding of a violation..$^{48}$ In fiscal year

\footnotetext{
43 The Board extensively regulates pre-election campaigning and may invalidate election results when such campaigning fails the "laboratory conditions" test. Such failures may fall short of an unfair labor practice because the Board is not restricted by the Act's proscriptions of unfair labor practices in monitoring pre-election activities. See generally Kenneth C. McGuiness and Jeffrey A. Norris, How to Take a Case Before the NLRB 221-30 (BNA, 5th ed 1986).

« 29 USC \$ 158(a)(5).

45 See Weiler, 96 Harv L Rev at 1778-81 (cited in note 8); Weiler, 98 Harv L Rev at 358-62 (cited in note 10). See also Freeman and Medoff, What Do Unions Do? at 233-39 (cited in note 39).

46 In calculating that increase, we included an outlier year, namely, 1959 , when 41,200 employees were offered reinstatement as a result of 32 cases in the trucking industry. With that year excluded, the annual average for the late 1950s falls to 1,496, and the average annual number of reinstatements rises fourfold between the 1950s and the 1980s. See 24 NLRB Annual Report 164, Table 4 n 2 (1959).

4753 NLRB Annual Report 248, Table 23 (1988).

48 Because of noncompliance, a substantial percentage of Board orders are judically reviewed. In 1988, 32 percent of the Board's orders against employers required judicial enforcement. That percentage has varied over time. The corresponding percentage was 62 percent in 1955 and 40 percent in 1980. 20 NLRB Annual Report 166, Table 8 (1955); 45 NLRB Annual Report 256, Table 7 (1980); 53 NLRB Annual Report 206-07, Table 7 (1988). See
} 
1988, the median time between a Board order and judicial enforcement was 430 days. $^{48}$ Thus, the median interval between filing a charge and judicial enforcement of an order was 1,192 days, or over three years.

The second element of the machinery that proponents of the rogue employer thesis cite is the ineffectiveness of these belated remedies. A Board remedy, even after judicial enforcement, may not be sufficiently burdensome to deter future violations. Discriminatorily discharged employees are entitled only to the gross pay they would have earned from the employer less the pay they actually (or should have) earned following their discharge. ${ }^{50} \mathrm{~A}$ lawless employer may consider the cost of that remedy (discounted by the probability of detection) warranted by the potential contribution of discriminatory discharges to an anti-union campaign. Such discharges discourage pro-union support by signaling to other employees that their support for a union may cost them their jobs. If discriminatory discharges avert or substantially delay union organization, the cost to the firm from a Board remedy may be less than the increased labor costs and the loss of managerial autonomy that are likely to result from a union victory. ${ }^{51}$

Proponents of the rogue employer thesis have also focused on employer illegalities that occur after Board certification of a union. Thus, an employer might benefit by refusing to negotiate at all with such a union or by engaging in "sham" bargaining (that is, bargaining not intended to lead to an agreement). During the protracted period in which the unfair labor practice case against the employer is being processed, employee support for the union, as

also Edward B. Miller, An Administrative Appraisal of the NLRB 26, 135, Table I (Pennsylvania, rev ed 1978). The declining ratio of orders requiring judicial enforcement works against the rogue employer thesis.

40 Table B: Comparison of Median Time (Days) Elapsed in Processing Cases Panel I (supplied by NLRB Executive Secretary) (on file with U Chi L Rev).

so See Charles J. Morris, ed, The Developing Labor Law 1634 n 6 (BNA, 2d ed 1983).

s1 In determining whether a Board proceeding is likely to restore an allegedly victimized employee to his job, a distinction must be drawn between reinstatement offers resulting from Board orders and from settlements. One study indicates that only 5 percent of employees offered reinstatement more than six months after their discriminatory discharges accepted such an offer. Typically much more time elapses between a discriminatory discharge and a Board reinstatement order. See U.S. General Accounting Office, Concerns Regarding Impact of Employee Charges Against Employers for Unfair Labor Practices (GPO, 1982) ("GAO Study") (study presented as report to House Subcommittee on Labor-Management Relations). Most reinstatement offers arise, however, from settlements, as distinguished from Board orders. Furthermore, such settlements usually are reached quickly, and employees generally accept reinstatement offers called for by the settlement terms-70 percent in fiscal year 1988. 53 NLRB Annual Report 195, Table 4 (1988). 
well as the union's ability to organize an effective strike, may disappear. Finally, when the Board holds that a violation occurred, it usually will order the employer only to resume bargaining with the union. A lawless employer whose unlawful stonewalling does not precipitate a strike may have postponed, for a substantial time, any increase in labor costs resulting from the unionization of its facility.

\section{The Significance of Employer Illegalities}

The rogue employer thesis emphasizes the surge, from 1950 to 1980 , in the number of unfair labor practice charges, in the amount of backpay awards, and in the number of workers ordered by the NLRB to be offered reinstatement by employers. Professor Weiler, an eminent exponent, if not the father, of this thesis, presents Table 4 as the basis of his conclusions. ${ }^{52}$

TABLE 4

UNFAIR LABOR PRACTICES BY EMPLOYERS, 1950-1980

\begin{tabular}{|c|c|c|c|c|c|c|}
\hline Year & $\begin{array}{c}\text { Certification } \\
\text { Elections } \\
\end{array}$ & $\begin{array}{c}\text { Charges } \\
\text { Against } \\
\text { Employers }\end{array}$ & $\begin{array}{l}\S 8(a) 3 \\
\text { Charges }\end{array}$ & $\begin{array}{c}\text { Fraction } \\
\text { Found } \\
\text { Meritorious }\end{array}$ & $\begin{array}{l}\text { Backpay } \\
\text { Awards } \\
\text { (Average } \\
\text { Amount) }\end{array}$ & Reinstatees \\
\hline 1950 & 5619 & 4472 & 3213 & NA & $\begin{array}{r}2259 \\
(\$ 477)\end{array}$ & 2111 \\
\hline 1955 & 4215 & 4362 & 3089 & $\mathrm{NA}$ & $\begin{array}{r}1836 \\
(\$ 428)\end{array}$ & 1275 \\
\hline 1957 & 4729 & 3655 & 2789 & $\mathrm{NA}$ & $\begin{array}{l}1457 \\
(\$ 354)\end{array}$ & 922 \\
\hline 1960 & 6380 & 7723 & 6044 & $\begin{array}{c}29.1 \% \\
\text { (overall) }\end{array}$ & $\begin{array}{r}3110 \\
(\$ 335)\end{array}$ & 1885 \\
\hline 1965 & 7576 & 10,931 & 7367 & $\begin{array}{c}35.5 \% \\
\text { (overall) }\end{array}$ & $\begin{array}{r}4644 \\
(\$ 599)\end{array}$ & 5875 \\
\hline 1970 & 7773 & 13,601 & 9290 & $\begin{array}{c}34.2 \% \\
\text { (overall) }\end{array}$ & $\begin{array}{r}6828 \\
(\$ 403)\end{array}$ & 3779 \\
\hline 1975 & 8061 & 20,311 & 13,426 & $\begin{array}{c}32.3 \% \\
\text { (employer) } \\
30.2 \% \\
\text { (overall) }\end{array}$ & $\begin{array}{r}7405 \\
(\$ 1524)\end{array}$ & 3816 \\
\hline 1980 & 7296 & 31,281 & 18,315 & $\begin{array}{c}39.0 \% \\
\text { (employer) } \\
35.7 \% \\
\text { (overall) }\end{array}$ & $\begin{array}{c}15,642 \\
(\$ 2054)\end{array}$ & 10,033 \\
\hline
\end{tabular}

Note: Reproduced from Paul Weiler, Promises to Keep: Securing Workers' Rights to Self Organization under the NLRA, 96 Harv L Rev 1769, 1780, Table II (1983). 1777.

s2 See Weiler, 96 Harv L Rev at 1780, Table II (cited in note 8); see also id at 1769 , 
From that table, Professor Weiler draws two problematic conclusions. First, he suggests that about 10,000 workers were fired in 1980 for involvement in representation campaigns. ${ }^{53}$ Second, generalizing beyond 1980, he states: "Astoundingly, ... the current odds are about one in twenty that a union supporter will be fired for exercising rights supposedly guaranteed by federal law" that has so often been repeated ${ }^{55}$ as virtually to have become part of labor relations folklore.

Professor Weiler highlights the 10,033 reinstatees in 1980 , without mentioning three troublesome points. First, the 1980 figure is obviously a substantial departure from the much lower 1975 figure and from the average of prior and subsequent years, as is shown in Table 3. Second, the number of reinstatees and the amount of backpay, although on an uptrend beginning in 1950, shows considerable fluctuation. By contrast, the decline in the unions' election success rate from the early 1950 s to the early 1980 s has been steady and progressive, failing to reflect the substantial year-to-year variations in backpay awards and the number of reinstatees. This failure suggests that other factors may be more important than employer misconduct in unions' organizational defeats.

Third, Weiler glosses over the fact that the 10,000 reinstatees in 1980 arose from all unfair labor practice charges, not just from those that were representation-related. Consequently, the estimate that 10,000 employees "were fired in 1980 for involvement in representation campaigns" $"$ is questionable. As we will develop be-

s3 Id at 1781. Weiler's 10,000 figure for 1980 is based on the following argument: Virtually all of the 10,000 employees entitled to reinstatement were discharged during organizational campaigns. Id. The Board obtained backpay for another 5,000 in 1980, many of whom had been fired but had settled for monetary relief, without reinstatement. Finally, other workers were illegally fired, but charges covering them were not filed or could not be substantiated. Id. Below we consider the difficulties with the foregoing argument.

s4 Id. Weiler has, however, also said that "most employers still do fight within the legal rules of the contest." See Paul Weiler, The Representation Gap in the American Workplace (unpublished manuscript, Aug 1988), quoted in Troy, 13 Harv J L \& Pub Pol at 595 (cited in note 27).

${ }^{85}$ Weiler's ratio is set forth in Freeman and Medoff, What Do Unions Do? at $233 \mathrm{n} 12$ (cited in note 39); The Failure of Labor Law-A Betrayal of American Workers, in Merrifield, St. Antoine, and Craver, Labor Relations Law (cited in note 39); Charles B. Craver, The NLRA at Fifty: From Youthful Exuberance to Middle-Aged Complacency, 36 Labor L $\mathrm{J}$ 604, 612 (1985), quoted by U.S. Dept. of Labor, Labor Law and the Future of LaborManagement Cooperation 9 (BMLR No 104, 1986); Statement of Chairman William Clay before the House Labor Subcommittee on Labor-Management Relations on Enforcement of Landrum-Griffin Act Provisions, 26 Daily Labor Rep (BNA) E-1 (Feb 8, 1984).

${ }^{68}$ Weiler, 96 Harv L Rev at 1781 (cited in note 8). 
low, ${ }^{57} \S 8(\mathrm{a})(3)$ not only proscribes such firings but also extends far beyond the organizational context. Furthermore, during the 1960s, interpretations of that section generated new grounds for NLRB backpay orders that enabled large numbers of employees to receive a remedy for employer misconduct in contexts far removed from organizational campaigns,

Recognizing that not all discriminatory discharges are representation related, Professor Weiler relies primarily on a 1978 estimate by the NLRB's General Counsel that 90 percent of such discharges would occur during either organizational campaigns or first contract negotiations. ${ }^{58}$ Reliance on that estimate, however, presents several difficulties. First, discharges during first contract negotiations usually occur after a union has won an election. Consequently, a union's loss of an election cannot be attributed to such discharges even though they might lead to a union's subsequent loss of majority support or might adversely affect unions in other elections. More important, the General Counsel presented the 90 percent estimate under circumstances that impair that figure's usefulness in determining the percentage of charges and violations of $\S 8(\mathrm{a})(3)$ arising from the organizational context. The General Counsel did not indicate the basis for that estimate. Furthermore, he did not even purport to reflect data collected under existing legislation. Rather, the figure was merely a forecast of the added workload for the General Counsel's office ${ }^{59}$ if the proposed Labor Reform Act of 1977 were enacted. ${ }^{60}$ That act would have imposed

67 See notes $72-81$ and accompanying text.

68 See Weiler, 96 Harv L Rev at 1781 n 35 (cited in note 8).

so John Irving, the NLRB's general counsel when the Board made its 90 percent estimate, criticized the 1:20 ratio (see text at note 54), urging, as Weiler had indicated, that most reinstatements resulted from settlements without any adjudication of a violation. See John Irving, The Board's Representation Process: Another View, in Charles J. Morris, ed, American Labor Policy 108, 111 (BNA, 1987). See also Departments of Labor and Health, Education and Welfare Appropriations for 1979, Hearings Before the Subcommittee on the Departments of Labor and Health, Education and Welfare of the House Committee on Appropriations, 95th Cong, 2d Sess 742, 744, 760-761 (1978) (“House Hearings").

so See HR 8410, 95th Cong, 1st Sess 52 (Oct 7, 1977), reprinted in Labor Law Reform Act of 1978, Hearings on HR 8410 before the Senate Committee on Human Resources, 95th Cong, $2 d$ Sess 3 (1978) ("Senate Hearings"). The Labor Reform Act, if enacted, would have created stronger incentives for employees to file charges alleging that violations of $\S 8(a)(3)$ had occurred during an organizational campaign or in the interval between recognition of a union and the negotiation of a first contract. The proposed changes in the existing legislation included: (1) double pay for victimized employees, which was later reduced in the Senate to 1.5 times the amount of lost wages (see S 2467, § 9(4), 95th Cong, 2d Sess (1978), reprinted in Senate Hearings at 45 and 61 ); (2) priority treatment by the NLRB; (3) interim injunctive relief; and (4) a requirement for reinstatement of discharged employees pending the NLRB's resolution of the charges prompted by their termination. The bill, however, 
additional responsibilities on the General Counsel's office in relation to employees allegedly discharged during an organizational campaign or prior to a first contract. The General Counsel, urging that these added responsibilities called for a larger appropriation, presented the 90 percent estimate without specifying its basis. Plainly, such an unsupported estimate that was the opening gambit in an appropriations hearing is a shaky basis for projecting the mix of $\S 8(a)(3)$ charges in a different legal environment.

More important than the accuracy of the General Counsel's or Professor Weiler's estimates regarding the context of discriminatory discharges is whether there has been a causal relationship between such discharges and the steep and steady decline in union success rates in NLRB elections. Professor Weiler acknowledges that the study by Getman, Goldberg, and Herman ${ }^{61}$ poses a major challenge to the existence of such a relationship, but he and others criticize the methodology and the conclusion of that study ${ }^{62}$ This question of causality has received a good deal of attention, ${ }^{63}$ and

died in the Senate (see 124 Cong Rec 18,399-400 (June 22, 1978)), and the incentives that it would have created did not materialize. Consequently, the General Counsel's 90 percent estimate is flawed as an indicator of the percentage of $\S 8(\mathrm{a})(3)$ charges arising from an organizational context under existing legislation.

Greater backpay liability would have increased the incentive for filing charges and, accordingly, the deterrent against unlawful discharges. Because the government provides counsel, litigation expenses would not have been a substantial restraint on filing such charges-including dubious ones-but might well have affected the willingness of the Board's staff to issue a complaint and to prosecute or settle it. The net result of these conflicting considerations is uncertain, but it seems likely that the reduction in the ratio of litigation costs to the liability involved would have hampered settlements. See Miller, $A n$ Administrative Appraisal at 118, 121-22 (cited in note 48). For details of the estimate by the Board's General Counsel and Chairman of the increased workload that would have resulted from the enactment of HR 8410, see House Hearings at 745 (cited in note 59).

61 Julius G. Getman, Stephen B. Goldberg, and Jeanne B. Herman, Union Representation Elections: Law \& Reality (Russell Sage, 1976). Getman et al responded to their critics in Stephen B. Goldberg, Julius G. Getman, and Jeanne M. Brett, Union Representation Elections: Law \& Reality: The Authors Respond to the Critics, 79 Mich L Rev 564 (1981). See also Laura Cooper, Authorization Cards and Union Representation Election Outcome: An Empirical Assessment of the Assumption Underlying the Supreme Court's Gissel Decision, $79 \mathrm{Nw}$ U L Rev 87 (1984).

${ }^{62}$ Weiler, 96 Harv L Rev at 1782-83 (cited in note' 8 ); William T. Dickens, The Effect of Company Campaigns on Certification Elections: Law and Reality Once Again, 36 Industrial \& Labor Rel 560, 561 (1983).

${ }^{63}$ See references in Bernard D. Meltzer and Stanley D. Henderson, Labor Law: Cases, Materials, and Problems $115 \mathrm{n}$ i, $117 \mathrm{nn}$ j \& k, $119 \mathrm{n}$ m (Little, Brown, 3d ed 1985). See Robert F. Flanagan, Labor Relations and the Litigation Explosion ch 4 (Brookings Institution, 1987) (expressing doubt, at 58-59, about a causal connection between unlawful discharges (among other violations) and election outcomes). Indeed, some studies have emphasized that discriminatory discharges may backfire and encourage, rather than discourage, organization. See Hoyt W. Wheeler and John A. McClendon, The Individual Decision to 
we do not intend to revisit it here. Instead, we propose to highlight aspects of the legal environment that have sometimes been neglected in discussions of the rogue employer thesis and the increase in unfair labor practice charges and complaints.

The neglected legal factors include: an expansion in the NLRB's effective and statutory jurisdiction, the frequency with which charges and findings of violations of $\S \S 8(a)(3)$ and $8(a)(5)$ of the NLRA arise out of contexts remote from either organizational campaigns or first-contract negotiations, and changes in NLRB doctrine that appear to have increased both the propensity to file charges against employers and the number of backpay awards, particularly the number of awards involving large amounts of money and large numbers of reinstatees. An exploration of those matters, as well as our study of Board adjudications and settlements, will show the flaws in both the well-known 1:20 ratio and the conclusion that increases in charges of employer unfair labor practices have been a major factor in U.S. deunionization.

\section{Legislative and Doctrinal Framework}

\section{A. The Expanding Jurisdiction of the NLRB}

Beginning in the 1960s, inflation as well as administrative and statutory changes expanded the Board's docket. Although inflation appears to have caused only a modest expansion, ${ }^{64}$ a much larger and potentially significant increase resulted from the extension of the Board's jurisdiction through administration and legislation. Thus, its jurisdiction was extended to private and nonprofit colleges or universities, ${ }^{65}$ United States postal employees, ${ }^{66}$ proprietary hospitals, ${ }^{67}$ nursing homes, ${ }^{68}$ and non-profit hospitals. ${ }^{68}$

Unionize 47, 65, in George W. Strauss, ed, The State of the Unions (Industrial Relations Research Association, 1991); John J. Lawler, Unionization and Deunionization: Strategy, Tactics, and Outcomes 231 (South Carolina, 1990).

o4 The Board, under its 1958 yardsticks, would exercise its statutory jurisdiction over a firm only if its annual volume of business met the minimum prescribed by the applicable yardstick. See NLRB Press Release, R 576 (Oct 2, 1958). Congress in 1959 barred the Board from raising these minima, and, accordingly, appeared to have barred the Board from taking account of the results of inflation. Landrum-Griffin Act, 29 USC $\S 164(c)(1)$ (1982). See Bernard D. Meltzer and Robert J. LaLonde, Inflation \& the NLRB: A Case of Fortuitous Regulatory Expansion, Regulation 43 (Sept-Oct 1980). But given the relatively low dollar amounts embodied in the Board's 1958 yardsticks, it is doubtful that inflation caused "a large increase in the Board's docket." Flanagan, Labor Relations and the Litigation Explosion at 31-32 (cited in note 63).

os Cornell University, 183 NLRB 329 (1970); 35 Fed Reg 18370 (Dec 3, 1970).

s8 Act of August 12, 1970, 39 USC $\S 1209$ (1988).

67 Butte Medical Properties, 168 NLRB 266, 267-68 (1967).

so University Nursing Home, Inc., 168 NLRB 263, 264 (1967).

6o Act of July 26, 1974, 29 USC \$§ 152(2), (14). 
Professor Flanagan has estimated that this jurisdictional expansion accounted at most for a 20-25 percent increase in charges filed with the Board. ${ }^{70}$ Under the higher end of that estimate, 25 percent of the increased charges against employers might have resulted from the expansion in the Board's jurisdiction, rather than from an increase in employer misconduct. Even though this jurisdictionally-related increase is far from negligible, it has sometimes been neglected in attempts to measure and explain increased employer violations, actual and alleged. ${ }^{71}$

\section{B. The Applicability of Section 8(a)(3) Outside the Organiza- tional Context}

Similarly, there has sometimes been a failure to appreciate the extent to which § 8(a)(3) provides the basis for backpay and reinstatement in situations far removed from the organizational context. Section 8(a)(3) may operate to protect a single employee seeking either to induce some form of group action other than an election or to invoke a right established by a collective bargaining agreement. ${ }^{72}$ It may also operate when an employer closes or relocates a unionized plant in order to escape unionization. But most important for our immediate purposes has been the application of $\S 8(a)(3)$ to disputes arising out of established and actual or alleged bargaining impasses. Such disputes may, for example, arise from strikes or lockouts followed by the hiring or retention of replacements. ${ }^{73}$

70 See Flanagan, Labor Relations and the Litigation Explosion at 30-32 (cited in note 63). Expansion of the NLRB's jurisdiction would presumably increase the NLRB's unfair labor practice docket in general. Although Weiler focused on discriminatory discharges in the organizational context, he also referred to the increase in ULPs in other contexts. See Weiler, 96 Harv L Rev at 1769 (cited in note 8). Furthermore, jurisdictional expansion would presumably lead to an increase in $\$ 8(\mathrm{a})(3)$ charges and violations arising both from established bargaining relationships and organizational contexts. Nonetheless, such an expansion might not affect the ratio of discriminatory discharges to pro-union voters in NLRB elections. Presumably, such an expansion would affect both the denominator (the number of pro-union voters in NLRB elections) and the numerator (the number of discriminatorily discharged union supporters). There is scant basis for suggesting that a different ratio would emerge in areas newly subjected to NLRB jurisdiction.

${ }^{71}$ For example, Weiler, 96 Harv L Rev at 1769 (cited in note 8), does not mention jurisdictional changes.

${ }^{72}$ NLRB v City Disposal Systems, Inc., 465 US 822, 831 (1984).

${ }^{73}$ Such measures of economic warfare in the context of established bargaining relationships are covered by an intricate body of regulation, only a few aspects of which will be touched on here. That regulation distinguishes between "economic strikes" (those seeking better terms or conditions of employment) and "unfair labor practice strikes" (those caused 
Unfair labor practice charges are likely to be filed after an employer hires replacements and denies reinstatement to strikers. When such charges are upheld, Board remedial orders tend to involve many more employees and much more backpay than do Board remedies for discriminatory discharges in the organizing context. In addition, litigation precipitated by retention of replacements and denial of reinstatement to strikers is likely to be hardfought and protracted because of the competition between strikers and replacements for the same jobs, the labor movement's traditional repugnance for "scabs," and the employer's potentially high backpay liability. Consequently, there tends to be an even greater than usual time lag between the occurrence of the alleged offense and the remedy ordered by the Board or embodied in a settlement.

The tendency of unusually high backpay awards, as well as protracted proceedings, to arise from resort to replacements for strikers or from employers' rejection of strikers' back-to-work offers is illustrated by three well-known cases: Kohler Co., ${ }^{74}$ NLRB v Erie Resistor Corp.,$^{75}$ and American Cyanamid Co. $v$

or prolonged by an employer's unfair labor practices). See generally Robert A. Gorman, $B a-$ sic Text on Labor Law, Unionization, and Collective Bargaining 339-49 (West, 1976). "Economic strikers" are in general entitled to get their jobs back upon making an unconditional back-to-work offer only if they have not been permanently replaced. "Unfair labor practice strikers" have more statutory protection. Even though their employer has purported to hire "permanent replacements," such strikers are entitled to bump those replacements by making an unconditional offer to return to work. Furthermore, a change in Board doctrine during the 1960s expanded the protection accorded to unfair labor practice strikers by preserving their reinstatement rights even though they had engaged in misconduct-such as violence, actual or threatened-that would not have been protected but for the employer's unfair labor practice. See discussion in note 74 .

74128 NLRB 1062, 1102-08 (1960). In Kohler, the Board had ruled that even unfair labor practice strikers could be lawfully fired for engaging in normally unprotected activities, such as violence against strike replacements. The reviewing court rejected that position on the ground that the Board should have applied the Thayer doctrine. See NLRB $v$ Thayer Co., 213 F2d 748 (1st Cir 1954). Under Thayer, the Board, in connection with a potential reinstatement award, "must consider both the seriousness of the employer's unlawful acts and the seriousness of the employees' misconduct." See Local 833, UAW v NLRB, 300 F2d 699, 702 (DC Cir 1962). For later stages of this case, see Kohler II, 148 NLRB 1434 (1964) (on remand), aff'd per curiam by an equally divided court, 345 F2d 748 (DC Cir 1965). The Board's reinstatement order after remand covered approximately 1,800 employees. See 148 NLRB at 1453. The final settlement was for $\$ 3$ million in backpay and $\$ 1.5$ million in pension adjustments distributed to approximately 1,800 employees. See 31 NLRB Annual Report 13 (1966); 243 Daily Labor Rep (BNA) AA-1 (Dec 17, 1965); 244 Daily Labor Rep (BNA) A-14 to A-17 (Dec 20, 1965); 251 Daily Labor Rep (BNA) A-7 (Dec 30, 1965). Furthermore, the Board, before its supplemental decision in Kohler, had announced its acquiescence to the Thayer doctrine. See Blades Manufacturing Corp., 144 NLRB 561, 567 (1963), enforcement denied on other grounds, 344 F2d 998 (8th Cir 1965).

75373 US 221 (1963). In Erie Resistor, the Court addressed the question of job entitlements some time after a strike settlement when layoffs became necessary. It upheld the 
$N L R B .{ }^{76}$ The American Cyanamid case is a dramatic illustration. Its settlement, which was reflected in the NLRB's annual report for the 1980 fiscal year, ${ }^{77}$ was the largest in the Board's history to that date and called for approximately $\$ 10.5$ million in backpay, plus $\$ 1.4$ million in interest. That settlement, moreover, accounted for more than one-third of the total backpay resulting from orders issued, or settlements approved by, the Board in fiscal 1980.

The disposition of one big case like American Cyanamid may contribute significantly to substantial year-to-year fluctuations in backpay entitlements. Plainly, the disposition of such cases in one year rather than another results from the vagaries of the litigation or settlement process. The accidental nature of the time of disposition underscores the potential for error in implying a causal link between the amount of backpay granted, or the number of employees offered reinstatement, in a given year and union election success rates in the same or proximate year(s). Specifically, such risks arise from highlighting one year-1980 - as the high point for backpay entitlements and reinstatements and as the low point for union victories in NLRB elections. ${ }^{78}$

Large backpay orders based on $\S 8(\mathrm{a})(3)$ violations may arise not only from work stoppages but also from the closing of part or all of a plant in order to escape unionization. The well-known groundbreaking case of Textile Workers Union v Darlington Manufacturing $\mathrm{Co}^{79}$ is illustrative. In that case, the closing of a

Board's condemnation of an employer's grant of superseniority to those who had worked during the strike-a grant that would have insured that full-term strikers would be laid off before permanent replacements or strike-defectors. The Board had held superseniority unlawful regardless of whether granting it was necessary for hiring replacements. In Erie Resistor, at least 129, and possibly more than 200 , strikers benefited from the backpay order. See the Board decision and the trial examiner's report, 132 NLRB 621, 621-24, 646 (1961).

${ }^{76} 592$ F2d 356 (7th Cir 1979). During an economic strike, the employer, without bargaining with the union, permanently subcontracted work out of the bargaining unit, thereby committing an unfair labor practice and converting the strike into an unfair labor practice strike. Subsequently, the company rejected the strikers' unconditional back-to-work offers, made after the union had rejected the company's request for a one-year strike ban. The court upheld the Board's determination that the company had violated $\$ 8(\mathrm{a})(3)$.

77 See 247 Daily Labor Rep (BNA) A-8 (Dec 22, 1979). That settlement, reached on approximately December 22, 1979, fell within the NLRB's 1980 fiscal year, which ran from October 1979 through September 1980. See 45 NLRB Annual Report (1980).

${ }^{78}$ See Weiler, 96 Harv L Rev at 1776, 1780-81 (cited in note 8), for an illustration of this risky procedure. But as Weiler emphasizes, despite year-to-year variation in reinstatees and backpay awards, both tended to increase substantially from 1955 to 1980.

79380 US 263 (1965). The Court rejected the NLRB's holding that an employer, even if it completely closes its business, violates $\$ 8(\mathrm{a})(3)$ if closure was prompted by a desire to avoid unionization. See Darlington Manufacturing Co., 139 NLRB 241, 251-52 (1962). The Court distinguished the liquidation of an entire business from the closing of a plant that is 
plant-a part of a larger enterprise-after the union had won an election in the plant was ultimately held to be a violation of $\S 8(a)(3)$. On December 3, 1980, the parties settled the backpay claims for $\$ 5$ million-some 14 years after the plant closing. ${ }^{80}$

More recent developments also indicate that $\S 8(\mathrm{a})(3)$ cases involving large backpay payments and reinstatement offers to many employees often arise out of bargaining, rather than election, contexts. These cases are briefly described in the unusually long footnote below. ${ }^{81}$

part of a larger enterprise. Such a partial closing violates $\S 8(a)(3)$ if the employer's interest in another business is substantial enough to "promise . . . a benefit" from discouraging unionism there, the closing had that purpose, and the employer's relationship with the other business makes it "realistically foreseeable" that its employees will fear that their organizational activities will lead to closure. See 380 US at 275-76. On remand, the Board found a violation of $\S 8$ 8(a)(3). Darlington Manufacturing Co., 165 NLRB 1074 (1967), enf'd Darlington Manufacturing Co. $v$ NLRB, 397 F2d 760 (4th Cir 1968).

${ }^{\text {so }}$ See NLRB, Office of General Counsel, Press Release, R-1625 (Dec 3, 1980). Five hundred and fifty employees had begun the 1956 organizational campaign, which led to the union's certification. See Patricia Eames, The History of the Litigation in Darlington as an Exercise in Administrative Procedure, 5 U Toledo L Rev 595, 595 (1974). The NLRB Regional Director maintained that the Board's order (even though it mentioned only "employees") entitled all personnel, including supervisors, who had lost jobs because of the closing to reinstatement and backpay. Id at 601-02; see Darlington Manufacturing Co., 139 NLRB at 254-55, 261. The Board had not ordered the reopening of the closed plant; instead, it ordered the parties to bargain for preferential hiring of the former employees for jobs in the company's other plants. Id at 258-59, 261. This bargaining failed, and none of the employees was employed in the other plants. See Eames, 5 U Toledo L Rev at 602-03.

${ }^{81}$ See 130 Labor Rel Rep (BNA) 465-66 (Apr 17, 1989). The amount of the backpay and the context of the claim, as set forth in the NLRB General Counsel's Quadrennial Report for FY 1984 through FY 1988, appear below; supplementary information supplied by the NLRB's General Counsel's office in response to the authors' request appears in parentheses. See Norton J. Come, Deputy Associate General Counsel, Letter to Bernard D. Meltzer (May 9, 1989) (on file with U Chi L Rev).

(a) Con Agra: $\$ 7$ million in backpay to 1,700 potential claimants (successor employer did not hire a majority of former employees; charges of $\S \S 8(\mathrm{a})(1)$ and $8(\mathrm{a})(3)$ violations but not of $\S 8(\mathrm{a})(5)$ because union not seeking recognition through Board's processes).

(b) Marlene Industries Corp., 255 NLRB 1446 (1981): seven plant locations, $\$ 1.3$ million backpay to 300 discriminatees (organizational campaign begun in 1965 but no election occurred). The Board held that the employees had struck in protest against an unfair labor practice (discharge of another employee for engaging in protected activity). The disputed activities occurred in 1970. The ALJ referred to the employer's massive violations in response to the union's organizational campaign that began in 1965. Id at 1456. But the dispute resolved in this case does not appear to have been connected with an immediate election.

(c) United Mine Workers (A.T. Massey Coal): Over 150 unfair labor practice charges, several contempt-of-court actions, and a cease-and-desist order applying to the International, the Districts, and over 350 locals in three states (picket-line misconduct case arising from an economic strike following bargaining impasse).

(d) Communication Workers of America (Southwestern Bell), 828 F2d 479 (8th Cir 1987): Ten unions in 200 locations and $\$ 180,000$ in dues reimbursement for 575 employees (employees filed $\S 8(\mathrm{~b})(1)(\mathrm{A})$ failure-to-represent charge against the union based on union's 


\section{New Incentives for Section 8(a)(3) and Section 8(a)(5) Charges in the Organizational Context}

Adjudicative and legislative developments in 1959 and in the 1960s provided new incentives for filing unfair labor practice charges against employers, particularly charges of $\S \S 8(a)(1)$, $8(a)(3)$, and $8(a)(5)$ violations. One important development was Bernel Foam Products Co., Inc., ${ }^{82}$ which held that a union, even after losing an election, could maintain a refusal to bargain charge, together with other unfair labor practice charges, based on the employer's conduct between the filing of an election petition and the election. The Board, however, also held that a bargaining order based on such preelection conduct would issue only if the Board set aside the election. ${ }^{83}$

Unlawful discharges, among other forms of coercion, were grounds for upsetting an election. Hence, after a union lost an election, Bernel Foam created strong new incentives for charging employers with such discharges in the representation context. ${ }^{84}$ In

receipt of dues deductions after employee revocation of authorization to employer to check off dues).

(e) United Food and Commercial Workers International Union $v$ NLRB (Spencer Foods), 768 F2d 1463 (DC Cir 1985): \$9 million in backpay to 264 discriminatees (case involved a bargaining deadlock, a plant closure, a dispute as to "successorship,". and discrimination in hiring former employees when plant was reopened). For an analysis of the case, see 50 NLRB Annual Report 107-08 (1985).

(f) C.E. Natco, 282 NLRB 314 (1986): $\$ 2.6$ million in backpay to 1,100 discriminatees (dispute during bargaining for new contract, followed by unlawful lockout).

(g) Southern Florida Hotel \& Motel Ass'n (Doral Hotels), 245 NLRB 561, 577 (1979): $\$ 7$ million in backpay to 300 discriminatees (contract dispute resulting in economic strike).

(h) Dillingham Ship: $\$ 3$ million in backpay to up to 1,500 claimants (bad faith bargaining, unilateral contract changes, and discharge of "a number" of employees after alleged sabotage).

(i) ILWU (PMA): $\$ 1.2$ million in backpay to 1,700 claimants (massive hiring hall violations).

${ }^{82} 146$ NLRB 1277 (1964) (overruling Louis Aiello, 110 NLRB 1365, 1370 (1954)).

${ }^{83}$ See Irving Air Chute Co., Inc., 149 NLRB 627, 630 (1964), enf'd, 350 F2d 176 (2d Cir 1965). Two other considerations increased the importance of the developments described above. First, under $\S 9(\mathrm{c})(3)$ of the NLRA, after a valid election, another election is barred for a year. 29 USC $\$ 159(c)(3)$. Second, under $\S 8(b)(7)(B)$, recognition or organizational picketing is drastically limited for at least a year after a valid election. 29 USC § 158(b)(7)(B).

B4 In ruling on objections to elections, the Board does not deal with unfair labor practices as such, but only with whether pre-election conduct destroyed the "laboratory conditions" appropriate for a Board election. See generally Midland National Life Insurance Co., 263 NLRB 127, 129 (1982). Nonetheless, a union objecting to an election because of an employer's discharge of employees could easily file a related unfair labor practice charge. Under NLRB v Gissel Packing Co., 395 US 575 (1969), a union would frequently have a strong incentive to do so because of the bargaining order sanctioned by Gissel or because the union wanted to establish the voting eligibility of discharged employee(s). 
other words, a union's loss of an election might lead to its filing marginal charges, rather than marginal or unlawful employer conduct leading to the loss of an election..$^{85}$ Accordingly, the causal relationship usually postulated between union election failures and unfair labor practices charges against employers might in some circumstances be inverted.

Under NLRB $v$ Gissel Packing Co., ${ }^{86}$ a key to the issuance of a bargaining order in favor of a union despite its loss of an election became "the commission of unfair labor practices that interfere[d] with the election processes and tend[ed] to preclude the holding of a fair election."87 After Bernel Foam and Gissel, a union, even though it had lost an election, could gain bargaining rights by proving that it once had had a majority and that the employer had committed "serious" unfair labor practices. ${ }^{88}$ Discharges violative

ss Compare, for example, 98 Daily Labor Rep (BNA) A-5 (Oct 11, 1985) (union representative threatened to file a charge if union lost the election, contending that employer had threatened plant closure; employer rejoined that it had stated only that operations would continue only so long as it could remain competitive). To be sure, in the 1960 s and 1970 s, approximately 32 percent of all charges had merit. (i.e., led to the issuance of a complaint). See Flanagan, Labor Relations and the Litigation Explosion (cited in note 63); Weiler, 96 Harv L Rev at $1780 \mathrm{n} 34$ (cited in note 8). Overall percentages for a large class of charges do not, of course, necessarily apply to a subset of that class. Nonetheless, there is no reason to believe that the percentage of merit charges concerning dismissals in the organizational context has declined with the increase in such charges: issues of credibility and motivation are usually pivotal in the disposition of such charges, and the presence of such issues will usually lead to a complaint. See Andrea S. Chistensen, Major Surgery Not Required, in Morris, ed, American Labor Policy 304, 397-98 (cited in note 59). Disputes over motive present risks of error-both ways-for the NLRB and any other adjudicative system.

s8 395 US 575 (1969).

87 Id at 594. Ultimately, the Supreme Court made it clear that an employer faced with a bargaining demand, even though it was supported by a card-based majority, was not required either to recognize the union or to file an election petition. See Linden Lumber Div., Summer \& Co. $v$ NLRB, 419 US 301 (1974).

${ }^{88}$ Gissel, 395 US at 593-94, 614-15. In the mid-1960s, the number of bargaining orders based on card majorities increased sharply. Cases in which the Board found card majorities destroyed by unfair labor practices numbered 45 in 1962, 73 in 1963, 83 in 1964, 135 in 1965, 108 in 1966, 141 in 1967, and 139 in 1968. Memorandum from Robert Volger, NLRB Deputy Executive Secretary, to John H. Fanning, NLRB Chairman 2 (Aug 29, 1980) ("Volger Memorandum") (on file with U Chi L Rev). The Volger Memorandum divides these cases into those not involving an election, as in Franks Bros. Co. $v$ NLRB, 321 US 702 (1944), and those in which an election was held but set aside, as in Bernel Foam. The 1947 Taft-Hartley amendments to the Act had cast doubt on the Board's continued authority to order an employer to bargain on the basis of a card majority. See Gissel, 395 US at 585-86. The Board's mid-1960s decisions in Bernel Foam (1964), Gissel (1966), and related cases maintained that such authority had survived the Taft-Hartley amendments and thus may have prompted additional cases of both the Franks Bros. and Bernel Foam type.

From 1962 through 1979, bargaining orders based on card majorities averaged 78 per year or 1.9 percent of the number of certifications based on Board elections. See Volger Memorandum at 1-2. 
of $\S 8(a)(3)$, although not absolutely necessary for a Gissel-type bargaining order, are among the "hallmark violations" likely to warrant such an order. ${ }^{8 \theta}$ Thus, Gissel and its progeny provided still another strong incentive for filing of $\S 8(a)(3)$ charges by unions losing Board elections. ${ }^{80}$

Still another incentive for such filings arose from the retroactive effect of Gissel-type bargaining orders. Because of such retroactivity, the Board, in addition to issuing a bargaining order, would award backpay to workers damaged by an employer's unilateral action in, for example, reducing wages or fringe benefits without bargaining with a union after rejecting its demand that it be recognized as the employees' representative. ${ }^{.1}$ In other words, after issuing a retroactive bargaining order on the basis of Gissel, the Board assesses the legality of, and remedies the employer's conduct, as if the employer had been under an obligation to bargain as of the date to which the order is retroactive. Furthermore, when employees respond to such a rejection with a recognition strike, and the employer engages in contemporaneous and widespread unfair labor practices, the strike is treated as an unfair labor practice strike. ${ }^{92}$ Hence, the strikers are entitled to reinstatement upon making an unconditional offer to return to work. Finally, unfair labor practice strikers engaging in misconduct are entitled to the qualified protection provided by the Thayer doctrine. ${ }^{93}$ The prospect of securing such protection against permanent replacement and against discharge for otherwise unprotected conduct, coupled

${ }^{89}$ See Larid Printing, Inc., 264 NLRB 369, 370 (1982); General Stencils, Inc., 195 NLRB 1109, 1112 (1972) (Chairman Miller dissenting).

${ }^{80}$ In 1965 (apparently in anticipation of the Supreme Court's 1969 Gissel decision) there was a sharp increase in Gissel-type bargaining orders. See Howard Lesnick, Establishment of Bargaining Rights Without an NLRB Election, 65 Mich L Rev 851, 851 n I (1967); Comment, Refusal-to-Recognize Charges Under Section 8(a)(5) of the NLRA: Card Checks and Employee Free Choice, 33 U Chi L Rev 359, 387-88 (1966).

91 See Trading Port, Inc., 219 NLRB 298 (1975) (unilateral elimination of jobs); Lapeer Foundry, 289 NLRB No 126, 3 (Dec 20, 1988) (economically motivated layoffs without prior bargaining).

${ }_{82}$ Trading Port, 219 NLRB at 299; Road Sprinkler Fitters Local Union No. $669 v$ NLRB, 681 F2d 11, 26 (DC Cir 1982). A strike for recognition is ab initio an economic strike. See Road Sprinkler, 681 F2d at 20 . The union's majority support, coupled with employer misconduct serious enough to warrant a bargaining order, results in retroactivity for that order to the time of the recognition demand. Hence, the employer's misconduct converts the economic strike for recognition into an unfair labor practice strike, regardless of whether the strike for recognition would have continued in the absence of employer misconduct. Id at 26-29.

${ }^{83}$ See discussion in note 74 . 
with the potential for receiving backpay, plainly provides strong incentives for filing $\S 8(a)(3)$ and $8(a)(5)$ charges.

Somewhat surprisingly, new incentives for filing unfair labor practice charges against employers also resulted from the new restrictions on recognition and organizational picketing imposed on unions by $\S 8(\mathrm{~b})(7)(\mathrm{C})$, added to the NLRA in $1959 . .^{94}$ Such incentives arose during the 1960s from the Board's reinterpretation of that section ${ }^{95}$ and from the interplay between that reinterpretation and the Board's long-established "blocking charge" rule. Under that rule, the NLRB will generally abate a representation proceeding and delay an election when a party has filed an unfair labor practice charge alleging post-petition conduct serious enough to have interfered with an election. ${ }^{96}$

After that reinterpretation, a union, by charging an employer with an unfair labor practice, could strengthen its defense against a charge that its picketing had had a recognitional objective. Furthermore, the Board, under its "blocking-charge" rule, would not hold an election until an unfair labor practice charge against an employer had been disposed of unless the charging party executed a "Request to Proceed." In the $\S 8(\mathrm{~b})(7)(\mathrm{C})$ context, the Board's application of that rule permitted a union to avoid the expedited election that that section mandates if an election petition is filed within thirty days after the beginning of recognitional picketing. Thus, despite the filing of a timely election petition, the pendency of a charge against the picketed employer would block the operation of the election machinery until the disposition of the charge. If the Board deemed the charge frivolous and promptly dismissed it, the election machinery would be activated without substantially compromising the purpose of $\S 8(\mathrm{~b})(7)(\mathrm{C})$. But a non-frivolous charge against the employer, although ultimately held to be groundless by the Board or a court, served as a license for recognitional picketing during the typically protracted period before the

* Labor-Management Reporting and Disclosure Act of 1959, 29 USC $\S 158(b)(7)$ (1988)

${ }^{25}$ There is no need here for a detailed analysis of the changes in the Board's approach that progressively narrowed the scope of $\S 8(b)(7)$. See generally Bernard D. Meltzer, Organizational Picketing and the NLRB: Five on a Seesaw, 30 U Chi L Rev 78 (1962); Lee Modjeska, Recognition Picketing Under the NLRA, 35 U Fla L Rev 633 (1983). It is enough to say that $\S 8(\mathrm{~b})(7)$ restricts picketing only when it has "recognition or organization" as an object. Consequently, the Board, by a benign characterization of the objects of disputed picketing, could free picketing unions from those restrictions. For an illustration of the leeways in such characterization, see Local 259, UAW, 133 NLRB 1468 (1961).

96 See NLRB Field Manual § 11730 (GPO, 1967); Carlson Furniture Industries Inc., 157 NLRB 851, 852-53 (1966); McGuiness and Norris, How to Take a Case Before the $N L R B$ at 82 et seq (cited in note 43 ). 
Board (or a court) disposed of the case. Such a license undercut the basic purpose of $\S 8(\mathrm{~b})(7)(\mathrm{C})$, i.e., to shield employers and employees from extended recognitional picketing that might inflict such severe economic losses on both parties as to result in recognition of the union without regard to its majority support. As a result of the Board's new approach to $\S 8(\mathrm{~b})(7)(\mathrm{C})$, that section operated to provide new inducements to file unfair labor practice charges against employers, including $\S 8(\mathrm{a})(3)$ charges, whether frivolous or well-founded. ${ }^{97}$ Our data do not, however, provide a basis for estimating the extent to which those inducements increased unfair labor practice charges against employers.

\section{Section 8(a)(5) and Employer Resistance}

Commentators have suggested that employer refusals to bargain, like violations of $\S 8(a)(3)$, have contributed significantly to deunionization. Professor Weiler, for example, highlighted what he found to be a drastic decline in the rate at which certified unions secure a first contract, from 86 percent of the certified bargaining units in 1955 and 1960 to only 63 percent in $1980 .{ }^{98}$ Professor Weiler reminded us that a worker views certification as hollow if it fails to lead to a collective bargaining agreement..$^{99}$ But $\S 8(\mathrm{a})(5)$ charges or violations connected with such failures are, of course, not fungible, and the changing incidence of such charges or violations does not reveal the character of the employer's disputed conduct.

In order to get a better picture of such conduct, it is necessary to identify its context and its connection with statutory procedures and purposes. Such contextual analysis is especially needed when,

97 Before leaving $\S 8(\mathrm{a})(3)$, we note that in the 1960 s a new basis for $\S 8(\mathrm{a})(3)$ violations arose from the Board's recognition that a union's breach of the duty of fair representation (DFR) violates the Act. The Board, breaking new ground, held that such a breach violates $\S 8(\mathrm{~b})(1)(\mathrm{A})$ (making it an unfair labor practice for a union to restrain rights under $\S 7$ of the NLRA) and, in addition, the Board held that an employer may violate $\$ \S(a)(1)$ and $8(a)(3)$ by granting a union's request incompatible with its DFR. See Miranda Fuel Co. Inc., 140 NLRB 181 (1962), enforcement denied, 326 F2d 172 (2d Cir 1963). Such liability might result even though an employer might be unaware of a union's improper purpose. See Barton Brands, Ltd. v NLRB, 529 F2d 793 (7th Cir 1976); Barton Brands II, 228 NLRB 889 (1977). According to the company's lawyer, this dispute was settled by the company's agreeing to $\$ 300,000$ in backpay and reinstatement of 50 employees.

so Weiler carefully states that the 1980 figure comes from a 1979-81 AFL-CIO study that covered only units of at least 100 employees, but that other data for 1970 suggest an even lower first contract success rate in smaller units. Weiler, $98 \mathrm{Harv} L \mathrm{Rev}$ at 351,354 \& $\mathrm{n}$ 7 (cited in note 10).

99 Id at 352,354 . 
as was the case from 1960 to 1980 , changes in the economic environment foreshadowed potential changes in the business of the Board. A contextual breakdown of charges filed with the Board will be presented in Part III. As background, it may be useful to mention the importance of NLRB elections, the kinds of problems they raise, and the administrative and judicial procedures for resolving them.

\section{The election framework.}

A Board-conducted election is generally the means by which unions achieve initial recognition from an employer. ${ }^{100}$ In administering its election machinery, the Board must make a variety of determinations, including those relating to the timeliness of the election petition, the appropriateness of the bargaining unit, the compatibility of challenged pre-election conduct with the Board's "laboratory-conditions" standard, the eligibility of voters, and the handling of their ballots. ${ }^{101}$

Such issues implicate concerns important to the parties and the public. For example, the NLRB's decisions on "appropriate units" may determine whether there will be any collective bargaining in a plant or enterprise. Unions and employers have sought to gerrymander accordingly. ${ }^{102}$ Furthermore, such unit determinations will affect the suitability of bargaining structures for accommodating the competing interests of various employee groups and for achieving stable and orderly labor relations. ${ }^{103}$ Finally, the Board's policing of electioneering and the myriad details of elections implicates both the employees' self-determination interests and the integrity (actual and apparent) of the Board's processes.

An employer, like a union, has a right to participate before the Board in connection with the resolution of representation questions. But an employer (or a union) aggrieved by such a decision has, in general, no right to direct judicial review of the disputed decision. ${ }^{104}$ If, however, the Board certifies a union despite an em-

${ }^{100}$ We were unable to find time series data on "voluntary" recognitions. Compare Ross, The Labor Law in Action at 12 (cited in note 30) (breaking down the basis for recognition in a sample of NLRB cases that involved § 8(a)(5) charges).

${ }^{101}$ See generally Miller, An Administrative Appraisal ch 2 (cited in note 48).

${ }^{102}$ In order to curb such gerrymandering, Congress added $\$ 8(\mathrm{c})(5)$ to the Act in 1947. 29 USC $\$ 159$ (c)(5) (1988).

${ }^{103}$ See E.R. Livernash, The Relation of Power to the Structure and Process of Collective Bargaining, 6 J L \& Econ 10 (1963); Douglas L. Leslie, Labor Bargaining Units, 70 Va L Rev 353 (1984).

${ }^{104}$ See American Federation of Labor v NLRB, 308 US 401 (1940). 
ployer's objection to the unit or to the conduct of the election, the employer can get judicial review of the Board's representation determinations by refusing to bargain with the certified union. The employer's refusal would precipitate a $\S 8(a)(5)$ charge and, ultimately, a Board bargaining order in the resultant unfair labor practice proceeding. An employer is entitled to judicial review of such orders and the representation decisions on which the validity of both the Board's certification and its bargaining order depends. ${ }^{105}$ Thus, an employer's refusal to honor a Board certification may be prompted by a legitimate desire to get a court to determine whether disputed Board election determinations are compatible with the Act or with the NLRB's established standards.

An employer may, however, have another motivation for contesting an election before the Board and then in court: it may merely be playing for delay. ${ }^{106}$ A strategy of delay is sometimes appealing to anti-union employers because it may undermine the union's support and reduce the likelihood that the union will win a second election or achieve a first contract. ${ }^{107}$ In addition, even if a court rejects all the employer's objections to a certification and upholds the Board's remedial order, such orders typically are not onerous. Hence, the possibility of remedial action by the Board would not appear to be a forbidding prospect for employers bent on delay. ${ }^{108}$

Other costs associated with such a strategy may, however, be substantial. These may include: strikes for better terms and conditions; monetary liability, if the employer's unilateral action lowers employee benefits; reputational damage to the employer; lower employee morale; slowdowns that will receive protection under the Thayer doctrine; strikes that would qualify as unfair labor practice

${ }^{10 s}$ Id at 406; NLRB $v$ Hearst Publications, Inc., 322 US 111, 114 n 6 (1944).

${ }_{106}$ Unfair labor practice charges that turn on the validity of the Board's representation determinations typically are resolved much more quickly by the Board than other charges. The reason is that the Board has already determined the underlying questions during the representation proceeding and generally refuses to relitigate them in the unfair labor practice proceedings. See generally Magnesium Casting Co. $v$ NLRB, 401 US 137 (1971). Nonetheless, by seeking judicial review, an employer may, of course, substantially delay the fulfillment of its bargaining obligation.

${ }^{107}$ See Myron Roomkin and Richard Block, Case Processing Time and the Outcome of Representation Elections: Some Empirical Evidence, 1981 U Ill L Rev 75. Other studies have, however, questioned both the effect of such delays on, and their significance for, election outcomes. See Lawler, Unionization and Deunionization at 213-14 (cited in note 63).

108 The weakness of the NLRB's conventional remedies for $\$ 8(\mathrm{a})(5)$ violations is a familiar theme. See, for example, Frank W. McCulloch, Past, Present and Future Remedies under Section 8(a)(5) of the NLRA, 19 Lab L J 131 (1968). For the Board's fluctuations on remedial issues, see Meltzer and Henderson, Labor Law at 850-51 (cited in note 63). 
strikes, with resultant limitations on the employer's retention of replacements; and substantial litigation expenses. Such potential costs supplement, and may be more burdensome than, those imposed by a general Board order to the employer to bargain with a certified union.

2. The economic context and bargaining positions.

An additional source of first-contract failures is the bargaining impasse. Some impasses reflect a firm's exercise of its statutory right to engage in "hard bargaining"108 and to shape its bargaining positions so as to reflect competitive pressures. Other impasses result from "sham" bargaining" in which an employer purports to honor a certification and to bargain while in fact it is seeking to avert, rather than to reach, an agreement.

The distinction between hard, economically motivated bargaining (permitted) and sham bargaining (proscribed) is manifestly murky. ${ }^{111}$ That distinction reflects the basic dilemma that has plagued the NLRB from its creation: how to reconcile the tension between the "good faith bargaining" required by the NLRA and the private ordering of employment terms that the Act was not to disturb. ${ }^{112}$

Beginning in the late 1960s and the early 1970s, the economic environment created strong incentives for employers to engage in conduct that might lead to charges of $\S 8(\mathrm{a})(5)$ violations. That period included the oil shocks of the 1970s, stiffer foreign competition, a recession, numerous plant closings, and mass layoffs. ${ }^{113}$ Such an environment might well have increased hard bargaining in first contract negotiations (as well as increased challenges to certifications). Similarly, that environment may have led to an increase in charges that such bargaining had been an unlawful attempt to avoid any agreement rather than a lawful effort to contain costs in response to market forces. During the $1980 \mathrm{~s}$, moreover, employees

109 See NLRB v Tomco Communications, 567 F2d 871, 884 (9th Cir 1978).

${ }^{110}$ See J.P. Stevens \& Co., Inc. v NLRB, 623 F2d 322, 325-26 (4th Cir 1980); BorgWarner Controls, 198 NLRB 726 (1972); Gorman, Basic Text on Labor Law at 484-89 (cited in note 73).

111 See sources cited in note 110.

112 See H.K. Porter Co., Inc. v NLRB, 397 US 99, 103-09 (1970).

113 See R. McKenzie, Plant Closings: Public or Private Choices? 22-24 (Cato Institute, 1982), noting the connection between significant job losses in manufacturing and the closing of manufacturing plants. Because changes in manufacturing employment reflect both expansion and contraction of existing plants, opening of new plants, and closing of old plants, it is difficult to sort out the differing influence of those processes. Id at 40 . 
appeared to be less reluctant to cross picket lines and to work as replacements for strikers. We do not have data regarding the frequency with which employers, over time, have resorted to replacements. ${ }^{114}$ But there seems to be a widespread impression that their use has increased, in part because it has been easier to hire replacements and, in part, because more employers consider that expedient an appropriate and feasible countermeasure to a strike. ${ }^{115}$ Such impressions, whether they reflect reality, might well contribute to tougher bargaining positions by employers, which in turn might frustrate a first agreement and precipitate strikes and the hiring of replacements. Resort to replacements after a bargaining impasse and a first contract failure generates strong motives for filing unfair labor practice charges. Although it is not easy to disentangle economic motives from anti-union sentiments as such, the changing economic environment might well have been the key factor in tougher employer bargaining positions and resultant first contract failures.

\section{Plant closings, mergers, and acquisitions.}

The economic environment beginning with the late 1960s and the concomitant restructurings and adjustments highlighted a range of questions relating to established, as well as to new, bargaining relationships. These questions included: the employer's duty to bargain with an incumbent union over a decision to close a plant ${ }^{116}$ or over other decisions reducing jobs in a bargaining unit, such as decisions to subcontract ${ }^{117}$ all or part of unit work; the obligation of acquiring or "successor" employers to bargain with the

114 President Reagan's unusually tough response to the air traffic controllers' strike of 1981 included the use of strike replacements and the firing of the strikers in accordance with the federal statute criminalizing strikes by federal employees. See 5 USC $\$ 7311$ (1978); 18 USC \$ 1918 (1988). Some observers urged that that strike and its aftermath weakened workers' sense of solidarity and the entire labor movement; others disagree. See Bernard D. Meltzer and Cass R. Sunstein, Public Employee Strikes, Executive Discretion, and the Air Traffic Controllers, 50 U Chi L Rev 731, 794-95 n 304 (1983).

11s See Statement of Franklin Frazier, Director of Education and Employment Issues, Human Resources Division of the General Accounting Office before the Subcommittee on Labor, Senate Committee on Labor and Human Resources, 5-9 (June 6, 1990). Because of a lack of time series data, that study was, however, unable to document any increase in replacements. Id at 3 .

${ }^{116}$ See generally First National Maintenance Corp. $v$ NLRB, 452 US 666 (1981); Michael C. Harper, Leveling the Road from Borg-Warner to First National Maintenance: The Scope of Mandatory Bargaining, 68 Va L Rev 1447 (1982); Comment, Mandatory Bargaining and the Disposition of Closed Plants, 95 Harv L Rev 1896 (1982).

117 See Fibreboard Paper Products v NLRB, 379 US 203 (1964); Westinghouse Electric Corp., 150 NLRB 1574 (1965). 
predecessor's labor union or to honor the latter's collective agreement; ${ }^{118}$ and the propriety of unilateral employer changes in working conditions during the term of an agreement or during the hiatus between agreements. ${ }^{118}$

There is no need here to develop these issues. It is enough to suggest that an increase in $\S 8(a)(5)$ charges arising from them was not surprising, given the surrounding legal uncertainties, the potential for securing substantial backpay awards, the bleak alternatives for employees displaced from high-paying jobs in industries such as autos and steel, and the ideological cast to disputes arising from the clash between employers' claims to "managerial or entrepreneurial prerogatives" and workers' claims of "property rights" in jobs.

The distinction between $\S 8(a)(5)$ charges arising from established relationships and those arising from bargaining that does not lead to a "first contract" warrants a caveat. We do not mean to imply that apparently economically-motivated closings are necessarily free from any motive to curb union demands in other units or to escape unionization. Nonetheless, such closings generally are essentially different from employer tactics, such as sham bargaining, that are designed to deprive a union of the substance of its newly won certification. Plant closures typically involve more immediately significant economic stakes for a firm and its employees than does sham bargaining during post-certification negotiations or the firing of a few union adherents during an organizational campaign. Furthermore, plant closures raising issues under the NLRA usually involve potentially greater backpay liability than the kinds of illegality just described. ${ }^{120}$ Finally, the NLRA cannot provide

11 See generally NLRB v Burns Int'l Security Services, Inc., 406 US 272 (1972); Fall River Dyeing \& Finishing Corp. $v$ NLRB, 482 US 27 (1987); Herbert R. Northrup and Philip A. Miscimarra, Government Protection of Employees Involved in Mergers and Acquisitions ch 2 (Pennsylvania, 1989).

110 The legality of unilateral action also arises during first contract negotiations, but the regulation in that context is much less intricate than in established contractual relationships. See 29 USC § 158(d); also compare Gorman, Basic Text on Labor Law ch 20 at $\$ 13$ (cited in note 73) with id, ch 20 at $\$ 14$.

120 When an employer's decision to close a plant without bargaining over that decision has been held to violate $\S 8(\mathrm{a})(5)$, backpay has been ordered from the date of the decision until the parties have bargained to agreement on the relevant issues, a bona fide impasse has been reached, or until bargaining has, in effect, been waived by the union. See Production Molded Plastics, 227 NLRB 776, 778 (1977), enf'd, 606 F2d 451 (6th Cir 1979). Where, however, the violation results from a failure to bargain over the effects of a "permissive" closing, backpay begins to run from the Board's (rather than the employer's) decision. See $J-B$ Enterprises, Inc., 237 NLRB 383, 387-88 (1978). The distinction between these two related situations goes back at least to the Board's decision in Transmarine Navigation 
significant protection against plant closures prompted by loss of markets.

Transfers of unionized operations, like plant closures, are also potential sources of substantial backpay awards. Such transfers increased from 1960 through 1968, one of the great waves of merger and acquisitions in our history. ${ }^{121}$ Moreover, between 1955 and 1980 , there were significant doctrinal changes regarding the impact of $\S 8(a)(5)$ on the acquisition of a unionized business-so-called "successorship" problems. ${ }^{122}$ These developments may have spawned additional $\S 8(\mathrm{a})(5)$ charges in the context of established bargaining relationships. Thus, an increase in charges arising from mergers and acquisitions, as well as plant closings, would not be evidence of greater employer resistance to newly certified unions but might well reflect changes in underlying economic forces.

\section{The Context of NLRB Adjudications and Settlements}

Sections 8(a)(3) and 8(a)(5) are broad and apply to a wide variety of industrial relations contexts. Thus, classification of a case under one of those sections tells us little about the relationship between that case and a union's loss of an election or a winning union's inability to secure a first contract. Unfortunately, the NLRB organizes its statistics under these uninformative sectional rubrics.

In order to get a better sense of the business of the Board, we classified Board adjudications, as well as certain settlements, under five categories indicative of the context from which charges

Corporation, 170 NLRB 389 (1968).

${ }^{121}$ See David J. Ravenscraft and F.M. Scherer, Mergers, Sell-Offs, and Economic Efficiency 21 (Brookings Institution, 1987). Forty-four percent of acquisitions of manufacturing and mineral firms in the 27 years between 1950-77 occurred during 1966-70. Id at 22. An extensive body of caselaw in this area has emerged. See Northrup and Miscimarra, Government Protection of Employees at ch 4 (cited in note 118).

${ }_{122}$ Compare Chemrock Corp., 151 NLRB 1074, $1078-80$ (1965) (successor required to bargain with union before reducing the employees' wages or terminating their employment) with NLRB v Burns Int'l Securities Services, Inc., 406 US 272, 281-91 (1972) (rejecting Board's view that would have bound a "successor" to its predecessor's unexpired collective bargaining agreement).

Successorship cases also involved potentially large backpay awards when an employer made unilateral changes in employment terms before discharging its duty to bargain. The Supreme Court, however, reduced the risks of such awards by upholding in general a nondiscriminatory successor's right unilaterally to fix the terms on which it would employ the predecessor's workers. See Burns Int'l Security Services, 406 US 272 (affirming denial of enforcement of NLRB make-whole order in favor of employees damaged by unilateral changes in agreement). 
arose. ${ }^{123}$ Those categories encompass allegations of: (1) unlawful employer interference with an employee's rights when no union is present; (2) unlawful employer support of, or negotiation with, a union that had never demonstrated majority support in the unit; (3) encroachment on protected activity during organizational drives either before or after the filing of an election petition; (4) unlawful employer refusal to bargain or discrimination after the Board certified a union but prior to its securing a collective bargaining agreement; and (5) employer illegalities during established bargaining relationships regardless of whether the term of the collective bargaining agreement had expired at the time of the alleged violation. ${ }^{124}$ The following Section sets forth our findings regarding the industrial relations context of charges adjudicated by the Board or settled by the parties. Although we will occasionally relate our findings to various contentions concerning the rogue employer thesis, our reference to those contentions is not intended as an endorsement of them. We will reserve for Part IV an assessment of the significance of our contextual findings for that thesis.

\section{A. The Contexts of Board Adjudications}

In both 1955 and 1980, a significant percentage of Board adjudications addressed allegations of the kind highlighted by proponents of the rogue employer thesis. As Table 5 shows, approximately 25 percent of all Board adjudications involved allegations of discriminatory discharges during organizational drives. ${ }^{128}$ In addition, 12 percent of all 1955 adjudications and 18 percent of all 1980 adjudications addressed alleged employer refusals to bargain in good faith after certification but prior to a first contract. Fur-

12s For our contextual analysis of ULP charges, we drew separate random samples of Board decisions from 1955 and 1980. The 1955 sample consisted of 202 of the 304 Board decisions; the 1980 sample consisted of 202 of the 985 Board decisions. See 15 NLRB Annual Report 5 (1955) and 45 NLRB Annual Report 13 (1980). We chose those years for two reasons. First, 1980 marked a high point in the number of charges filed with the Board and has been the focus of literature on employer lawlessness. See Freeman and Medoff, What Do Unions Do? at 232-33 (cited in note 39); Weiler, 96 Harv L Rev at 1780-81 (cited in note 8). Second, in 1955, union density in the United States was comparatively high, while the number of NLRB adjudications was relatively low. For a more detailed description of those samples and an elaboration of our industrial relations categories, see the Statistical Appendix, Section II, pp 1010-11.

${ }^{124}$ A collective bargaining agreement may continue to operate even after its expiration date. See Nolde Brothers, Inc. v Local 358 Bakery \& Confectionery Workers Union, 430 US 243 (1977); Goya Foods, 238 NLRB 1465, 1467 (1978).

125 Some cases, because they involved multiple and varied allegations, fell into more than one of our charge-categories. 
thermore, the Board adjudicated more than three times as many charges in 1980 as in $1955 .{ }^{126}$ Consequently, our findings imply that there was a corresponding increase in the number of adjudications involving charges of discriminatory discharges during organizational campaigns, as well as charges of refusal to bargain in good faith after certification but prior to a first contract. Similarly, to the extent that our sample of Board adjudications is representative of the Board's total docket, our results are consistent with the thesis that an increase in such violations of the Act is associated with a decline in union successes both in NLRB elections and in securing first contracts.

Nonetheless, our analysis confirmed our presupposition that charges of discrimination arise from a variety of industrial relations contexts. Of adjudications addressing such charges, 58 percent in 1955 and 39 percent in 1980 involved alleged violations arising from nonorganizational contexts. ${ }^{127} \mathrm{~A}$ significant percentage of these allegations (45 percent in 1955 and 31 percent in 1980) arose within the context of established bargaining relationships. Furthermore, discrimination in such contexts potentially involves many reinstatees and large backpay awards. ${ }^{128}$ Thus, the substantial percentage of charges of "discrimination" arising from established bargaining relationships undermines the contention that 90 percent of $\S 8(a)(3)$ charges and violations arose from the organizational context. Our findings also are incompatible with the widely held belief that 1 in 20 union supporters were victimized by a discriminatory discharge during organizational campaigns.

There are two noteworthy differences between the $\S 8(\mathrm{a})(3)$ adjudications in 1955 and 1980. First, as Table 5 shows, the 1955 sample involved a larger percentage of allegedly union-instigated discharges in established bargaining contexts (ten percent of the 1955 adjudications compared to only one percent in 1980). Second, a much larger percentage of 1980 adjudications under $\S 8(a)(3)$ addressed allegations of employer discrimination in the organizational context that consisted of actions short of discharge (only five percent in 1955, compared to 25 percent in 1980).

The rogue employer thesis postulates not only that employers have increasingly resorted to discriminatory discharges during or-

${ }^{128}$ See note 123.

${ }^{127}$ See Statistical Appendix, Table A, for the percentages of all Board adjudications, of $\S 8(a)(3)$ adjudications, and of $\S 8(a)(5)$ adjudications, respectively, that address alleged violations in the industrial relations contexts described above.

${ }^{128}$ See notes 73-81 and accompanying text. 


\section{TABLE 5}

\section{CHARGES AGAINST EMPLOYERS IN NLRB ADJUDICATIONS [Percentage of Adjudications of Various Allegations]}

Type of Allegation

$\underline{1955} \underline{1980}$

Nonunion (or Nonadversary Union) Context:

Discharge for Concerted Activity

Employer-Assisted Union

$\begin{array}{ll}3 \% & 6 \% \\ 4 & 0\end{array}$

Organizational Context:

Discharge

$\begin{array}{rr}25 & 24 \\ 2 & 13 \\ 23 & 32 \\ 1 & 6\end{array}$

Campaign Misconduct

Extensive Misconduct-Gissel Order

Post-election/Prior to Agreement:

Discharge

$3 \quad 2$

Misconduct: Threats, etc.

02

Unilateral Change in Terms

Failure to Bargain with Newly Certified Union

Established Contract:

Discharge

Union-Instigated Discharge

Failure to Reinstate Strikers

Other Discrimination

Misconduct: Threats, etc.

Unilateral Change in Contract Terms

Failure to Provide Information

Notes: The statistics in this table are based on random samples of 204 NLRB-adjudicated cases in 1955 and 202 such cases in 1980. The "context" of the cases refers to the relationship between the employer, the employees, and the union when the violation allegedly occurred. "Nonunion" refers to charges that arose when there was no formal collective bargaining agreement in effect nor any evidence of union organizing activity. "Organizational" refers to alleged violations that occurred prior to or after the filing of an election petition, during the period between filing of the petition and the election, and after a campaign had been formally terminated. "Post-election/prior to agreement" refers to alleged violations that occurred after a union election victory had been certified by the NLRB but prior to a first contract. "Established contract" refers to alleged violations that occurred in relationships that had negotiated successfully at least one collective bargaining agreement. Sources: 15 NLRB Annual Report 5 (1955) and 45 NLRB Annual Report 13 (1980).

ganizational campaigns but also that the vast majority of employees offered reinstatement have been discharged during such campaigns. In order to assess that contention, we examined the context of adjudications that led to reinstatement offers. ${ }^{129}$ We found the following. First, in both years, employers had unlawfully dis-

120 The Board issued such orders in approximately one-third of our samples of 1955 and 1980 adjudications. 
charged one or more employees during organizational drives in 50 percent of the relevant adjudications. Second, a significant percentage of the Board's reinstatement orders arose from employer violations in the context of established bargaining contexts ( 30 percent of the 1955 reinstatement orders and 33 percent of the 1980 orders). ${ }^{130}$ Plainly, these findings strengthen our earlier doubts that 90 percent of $\S 8(\mathrm{a})(3)$ violations arose from the organizational context.

Our contextual analysis of $\S 8(a)(5)$ adjudications once again underscores the varied industrial relations contexts that generate charges of refusal to bargain in good faith. Of the adjudications addressing such allegations, 58 percent in both 1955 and in 1980 did not arise in the period after certification but prior to a first contract. Plainly, the rise in $\S 8(a)(5)$ adjudications resulted in part from an increase in charges remote from the post-certification, first-contract context. Nonetheless, 42 percent of our 1955 and $1980 \S 8(a)(5)$ adjudications addressed alleged violations after certification but prior to a first contract.

Furthermore, turning to Board bargaining orders, we found that 52 percent of 1980 orders remedied employer violations that occurred in that context. The magnitude of these percentages leaves open the possibility that a significant number of employers may be refusing to bargain in good faith with newly certified unions in the hope that union support will be eroded by a strategy of delay.

\section{B. The Contexts of Settled Cases}

Our Chicago sample, which is obviously small and parochial, is a problematic basis for extrapolations. Nonetheless, our findings imply that Board-adjudicated charges are not representative of the Board's total docket. A larger percentage of settled cases than Board adjudications involved $\S 8(a)(5)$ charges arising from established bargaining relationships. ${ }^{131}$ That fact suggests that extrapolations based on Board-adjudicated charges may overstate the sig-

${ }^{130}$ In 16 percent of the 1980 reinstatement orders and 5 percent of such 1955 orders, the Board remedied employer discharges for "concerted activity" in situations in which a union did not have, and did not seem to be seeking, representative status.

131 Table 6 indicates that 60 percent of the settled cases, compared to 46 percent of Board adjudications (from the 1980 sample), involved $\S 8(\mathrm{a})(5)$ charges. Furthermore, 62 percent of the settled cases, compared with 35 percent of the 1980 Board adjudications, arose out of established bargaining relationships. 
TABLE 6

SETTLEMENTS FROM THE NLRB

REGIONAL OFFICE IN CHICAGO

Frequency of $\S 8(a)(3)$ and $\S 8(a)(5)$ Charges:

Settlements resolving $\S 8(\mathrm{a})(3)$ charges

Settlements resolving $\S 8(a)(5)$ charges

$\%$ of

Settlements

45

60

Context of Charges:

Nonunion Context: Concerted Activity 6

Organizational Context 21

Post Election/Prior to Agreement $\quad 9$

Established Contract $\quad 62$

Most Common Allegations:

Unilateral Changes in Employment Terms 22

Discharges in Organizational Settings 18

Discrimination Other than Discharge or Bypassing Union in Established Relationship 13

Discharge in Established Relationship $\quad 8$

Involvement in Decertification Drive

8

Source: Random sample of 53 cases voluntarily settled by the parties in 1985 and 1986 on file in the NLRB's Regional Office in Chicago. For a description of the industrial relations contexts of the charges see Table 5 and the Statistical Appendix, Table A.

nificance of employer lawlessness in organizational or post-certification/pre-first contract contexts.

The most significant findings bearing on the importance of such lawlessness are as follows. First, as the last panel of Table 6 shows, employers were charged with discriminatory discharges during an organizational campaign in 18 percent of settled cases. This percentage is somewhat less than the corresponding percentage applicable to 1980 Board adjudications (24 percent). Second, as the middle panel of Table 6 shows, nine percent of the settled cases involved allegations arising from occurrences after certification but before a first contract. That percentage is also smaller than the corresponding percentage ( 23 percent) of such cases in our samples of Board adjudications. Consequently, inferences drawn from our sample of Board adjudications are not likely to understate, and may overstate, the significance of alleged discriminatory discharges during organizational drives or refusals to bargain in good faith prior to a first contract. 


\section{Reassessing the Role of Employer Lawlessness}

\section{A. Discharges During Organizational Drives}

In trying to determine the incidence of discriminatory discharges in the organizational context, we face at least three quite distinctive populations of unfair labor practice allegations: first, all charges of such discrimination; second, such charges that have survived the General Counsel's filtering process and have led to the issuance of a complaint (charges with merit); and finally, complaints that have led to a Board finding of an unlawful discharge and a remedial order calling for reinstatement and backpay. ${ }^{132} \mathrm{Ob}-$ viously, the universe of actual discriminatory discharges extends far beyond the last subset of cases. Indeed, many allegedly unlawful employee discharges during organizational drives are effectively concealed or settled..$^{133}$

Settlements of charges of such firings sometimes call for the employer to reinstate one or more employees. On the one hand, such settlements presumably involve a greater likelihood of an actual violation of $\S 8(\mathrm{a})(3)$ than do cases dismissed or withdrawn. On the other hand, some charges of unlawful discrimination are presumably settled by employers even though no such discrimination occurred. Such settlements might be prompted by a desire to avoid legal expenses, reputational damage, or industrial unrest. Because of such offsetting factors, estimates of the frequency of discharges in the organizational context are subject to error in both directions.

In order to make such an estimate, we drew on our finding that 50 percent of the Board's reinstatement orders were based on employer violations during organizational drives. That percentage, applied to all settled and adjudicated cases in which employees were offered reinstatement, indicates that in 1980, discriminatory

${ }^{132}$ Other subsets of ULP cases are those involving judicial affirmance or reversal of Board determinations. We have not dealt with those populations, in part, because the samples are too small to be representative of the total population of discharges remedied by backpay awards and reinstatement offers.

${ }^{133}$ The settlement of, and the issuance of a complaint in, a case may not be signifcantly different indicators of probable violations. Management lawyers report that they will not settle unless the General Counsel's office has indicated that a complaint is likely to issue or unless their own investigation indicates a strong likelihood of such action. Employers' lawyers sometimes know more about the charges than does the General Counsel, and they will encourage an early settlement when their information shows that a violation probably occurred or at least that a complaint is likely to issue. Consequently, pre-complaint settlements may frequently be as probative of a violation as post-complaint settlements. 
discharges may well have occurred in 20 percent of election campaigns. ${ }^{134}$

To estimate the number of discharged union supporters per pro-union voter in NLRB elections, we need to estimate the average number of employees covered by a reinstatement offer in cases arising from the organizational context. Our samples of Board adjudications in 1955 and 1980 do not permit reliable determinations of that number. ${ }^{195}$ But a basis for that determination is provided by a plausible GAO study of $\S 8(\mathrm{a})(3)$ cases that arose in 1979. That study found that employers discharged an average of $2.2 \mathrm{em}-$ ployees per complaint alleging discriminatory discharges during organizational campaigns. ${ }^{136}$

Using the GAO's study and our sample of Board adjudications, we estimated the number of union voters per discharged union supporter in 1980. For that year, we first estimated that 3,199 employees had been offered reinstatement because of unlaw-

134 This 1980 percentage was derived by multiplying the number of cases in which one or more employees were offered reinstatement $(2,851)$ by the fraction of Board reinstatement orders (0.51) in our sample of Board adjudications arising out of employer discharges during organizational campaigns. See 45 NLRB Annual Report 23, Table 4 (1980). That product $(1,454$ cases) was then divided by 7,296 , the number of collective bargaining elections in 1980, to arrive at 0.20 . See 45 NLRB Annual Report 270-72, Table 13 (1980). That result was not significantly altered when we substituted the number of 1980 elections for the 1979 number, in order to account for the time lag between the occurrence of the alleged violation and the closing date of a case. One difficulty with these calculations is that the numerator includes discharges during all phases of an organizational campaign, whereas the denominator measures the number of organizational campaigns by the number of elections. Because not all organizing drives lead to a petition, let alone an election, the number of organizational campaigns is greater than the number of NLRB elections. Hence, the 20 percent figure derived from the number of elections rather than the number of organizational campaigns may well overstate the frequency of discriminatory discharges aimed at averting unionization.

Iss NLRB Annual Reports do not identify the context of alleged or actual violations. Beginning in 1964, the NLRB has reported annually the number of adjudicated or settled cases leading to reinstatement. Such reinstatement offers averaged 3.1 persons per case between 1964 and 1988. Moreover, during that period, there has not been any tendency for that ratio to rise or fall. See 29-53 NLRB Annual Reports Table 4 (1964-88). We naturally would prefer an estimate of the ratio of persons offered reinstatements per case (in which such offers are made) in only those cases that arose from alleged violations during organizational drives.

136 The GAO studied " 400 section $8(a)(3)$ cases which the NLRB considered as having merit" from 11 of the Board's then 33 offices (i.e., the Regional Director had issued a complaint in those cases during 1979). The GAO's figure of 2.2 employees covered by each complaint was derived by dividing the number of employees allegedly discharged during organizational drives (394) by the number of complaints alleging such frings (176). See GAO Study at 4-5, Appendix I (cited in note 51). We assume that the 2.2 figure for cases involving complaints applies to cases involving Board findings of violations or settlements by the parties. 
ful discharges during organizational drives. ${ }^{137}$ Second, we used that number as the divisor into the 199,900 pro-union votes in NLRB elections in $1980 .{ }^{138}$ Hence, in 1980, approximately 1 in 63 union supporters, in contrast to Weiler's 1 in 20 ratio, may have been unlawfully discharged during organizational drives. ${ }^{139}$ Even the 1 in 63 ratio manifestly represents a serious denial of statutory rights to individual employees and a potentially serious impediment to effective union organization.

The 1 in 20 ratio for unlawful discharges during organizational campaigns apparently rested on three erroneous and interrelated assumptions: first, that most discharge allegations arose in organizational settings; second, that only an insignificant fraction of such cases arose during established bargaining relationships; and third, that each $\S 8(a)(3)$ violation arising from the organizational context is likely to result in substantially the same number of reinstatees as would result from $\S 8(\mathrm{a})(3)$ violations arising from an established bargaining relationship. As we indicated in Part III, ${ }^{140}$ our sample of Board adjudications suggests that the first two of those assumptions are erroneous. Fully one-third of the Board's reinstatement orders redressed violations arising out of established bargaining relationships. True, the fraction of such cases is less than the fraction arising from the organizational context. But, contrary to the third assumption, § 8(a)(3) violations arising from established bargaining settings are likely to involve significantly larger numbers of reinstatees and significantly larger backpay awards than violations in other settings. ${ }^{141}$

${ }_{137}$ This figure is derived by multiplying the number of 1980 adjudicated and settled cases involving reinstatement offers $(2,851)$ by the estimated fraction of such cases that arise in organizational settings (one-half) and by multiplying that product by the number of reinstatees per case (2.2). The number of 1980 cases is taken from 45 NLRB Annual Report 248, Table 4 (1980).

138 45 NLRB Annual Report 280, Table 15B (1980).

138 Focusing on the number of individuals covered by reinstatement offers, as distinguished from backpay awards, is appropriate for the following reasons. First, if there is strong evidence of a discriminatory discharge, the Board will generally reject a settlement unless it includes a reinstatement offer. Second, violations of $\S 8(a)(5)$, such as improper unilateral action or refusal to bargain in connection with plant closings, may generate backpay awards despite the absence of discriminatory discharge. See notes 116-20 and accompanying text. Third, some discrimination falls short of discharge. See text following note 128. Weiler's estimate does not expressly take account of the foregoing considerations or of the possibility that some settlements calling for backpay may result not from violations but from an employer's wish to avoid litigation expenses, industrial unrest, or unfavorable publicity. See Weiler, 96 Harv L Rev at $1780-81$ (cited in note 8).

140 See notes 125-30 and accompanying text.

\$1 See note 81 and text following note 73 . 
The well-known 20:1 ratio has been invoked in support of the thesis that unlawful discharges during organizational campaigns have become more pervasive. To test that thesis and to compare the implications of our method with Weiler's, we used both methods in estimating the numbers of union supporters discharged per union voter as well as the percentage of elections connected with employer conduct that led to reinstatement offers for the period from 1964 to $1988 .{ }^{142}$ As Table 7 shows, both procedures indicate that the number of discriminatory discharges during organizational drives increased significantly after the mid-seventies. ${ }^{143}$ However, as the first column of Table 7 shows, the estimates based on our contextual data regarding alleged employer unfair labor practices indicate that such discharges are much less common than Professor Weiler suggested. That difference reflects our finding that a substantial fraction of discriminatory discharges arose outside of the organizational context. ${ }^{144}$

Estimates based both on our methodology and on Professor Weiler's also indicate a sharp increase in the ratio of discharged union supporters to pro-union voters since the 1960s. However, as the second column of Table 7 shows, the estimates based on our data indicate that the ratio of such discharges is much lower than Professor Weiler suggests. Similarly, our estimates indicate a sig-

112 We chose this period because the NLRB statistics required for the calculations did not become available until 1964. 29 NLRB Annual Report 155 (1964).

14 An employer could implement a strategy of coercion by discharging only one person in a bargaining unit of, let us assume, no more than 75 employees. If bargaining units declined from, for example, 75 to 40 employees, that strategy would still require at least one discharge in a unit; the ratio of discharges to union supporters or votes would rise. Because Board elections have tended to involve progressively smaller units, an increase in that ratio would not be surprising, if one accepted the premise that employers generally view a discriminatory discharge as an effective anti-union measure. Furthermore, smaller firms, because they may well have more casual disciplinary procedures, would find it harder to prove the legitimacy of discharges during an organizational campaign that were alleged to be discriminatory. Any discharge of a union supporter during such a campaign-whatever the reason-becomes suspect and a potential $\$ 8(a)(3)$ violation. Board disposition of charges of such violations usually turns on an assessment of conflicting testimony and a determination of the employer's motive.

An employer may avoid an election if its resistance, legal and illegal, (or employee opposition to a union) denies a union the "substantial support" (usually 30 percent of the bargaining unit) necessary for the direction of a Board election. Our data do not permit us to estimate the extent to which employer illegalities forestall Board elections.

14 The percentage of cases leading to reinstatement offers that arose outside the organizational context was higher in our sample of Board adjudications ( 49 percent) than in the GAO's sample of $\S 8(\mathrm{a})(3)$ complaints (40 percent). That difference may reflect sampling error or differences between the populations of cases surveyed. See GAO Study at 5, Appendix I (cited in note 51). 


\section{TABLE 7}

\section{DISCHARGES DURING ORGANIZATIONAL DRIVES [Annual Average During Period]}

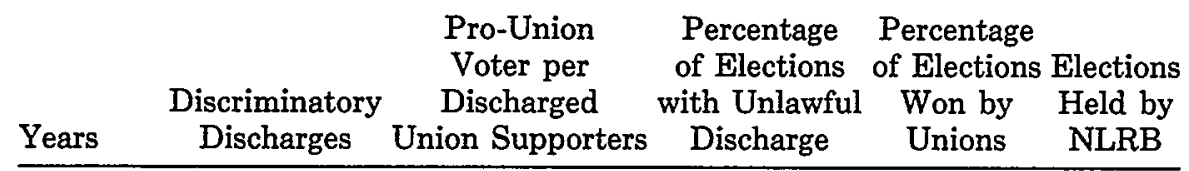

Panel A: Estimates Based on Context of ULP Charges and Remedies

$\begin{array}{rllrrr}1964-69 & 1,371 & 1 / 209 & 8 & 59 & 7,698 \\ 1970-74 & 1,342 & 1 / 196 & 7 & 54 & 8,298 \\ 1975-79 & 1,942 & 1 / 110 & 11 & 49 & 7,884 \\ 1980-84 & 2,812 & 1 / 57 & 20 & 46 & 5,049 \\ 1985-88 & 2,483 & 1 / 36 & 32 & 48 & 3,559\end{array}$

Panel B: Estimates Based on Professor Weiler's Methodology

$\begin{array}{llllll}1964-69 & 4,539 & 1 / 63 & 27 & 59 & 7,698 \\ 1970-74 & 4,317 & 1 / 61 & 24 & 54 & 8,298 \\ 1975-79 & 4,817 & 1 / 44 & 29 & 49 & 7,884 \\ 1980-84 & 6,844 & 1 / 19 & 62 & 46 & 5,049 \\ 1985-88 & 5,647 & 1 / 16 & 72 & 48 & 3,559\end{array}$

Notes: In Panel A, "Discriminatory Discharges" are estimated by multiplying the number of settled or Board-adjudicated cases leading to a reinstatement offer by 0.5 , the fraction of such cases estimated from our samples of 1955 and 1980 Board adjudications that arise from alleged violations of the Act during organizational drives by 2.2 , the estimated number of persons offered reinstatement per case. "Pro-Union Voter per Discharged Union Supporters" is estimated by dividing the number of discriminatory discharges (in column 1) by the number of voters supporting the union in NLRB elections. "Percentage of Elections with Unlawful Discharge" is estimated by dividing the estimated number of cases involving a discriminatory discharge during an organizational drive by the number of collective bargaining ("RC" or "RM") elections. Finally, the percentage of collective bargaining elections won by unions and the number of collective bargaining elections held by the NLRB are presented in columns 4 and 5, respectively. In Panel B, the figures in column 1 report the average number of employees offered reinstatement annually. The figures in column 2 are derived from the number of discriminatory discharges (in column 1) divided by the number of union voters in NLRB elections. The figures in column 3 are derived from the number of cases involving a discriminatory discharge (column 1 divided by 2.2 persons per case) divided by the number of elections. The figures in columns 4 and 5 are derived as in Panel A. Sources: 29-53 NLRB Annual Reports Tables 4 and 13 (1964-88); GAO Study (cited in note 51); and the authors' calculations based on 1955 and 1980 Board adjudications.

nificant increase, during the $1980 \mathrm{~s}$, in the percentage of elections connected with discriminatory discharges that led to a reinstatement offer. Once again, there is, however, a significant difference between our estimates and Professor Weiler's. As the third column of Table 7 shows, our estimate indicates that during the early 1980 s, when union victory rates were low, such unlawful discharges occurred in connection with 20 percent of NLRB elections. In con- 
trast, Weiler's methodology implies that such discharges occurred in connection with 63 percent of all election campaigns. ${ }^{145}$

Even though estimates based on our sample of Board adjudications indicate an increase in the incidence of discriminatory discharges, the correlation between the frequency of such discharges and declining union victory rates in NLRB elections is not stable. As the fourth column of Table 7 shows, the percentage of elections won by unions declined steadily from the late 1960s but appears to have stabilized during the mid-70s. By contrast, estimates of discriminatory discharges during organizational campaigns have continued to rise. During the 1980 s, the fraction of election campaigns where at least one employee may have been unlawfully discharged is much higher than in previous years. The rate of union election victories in the 1980s, however, is not significantly lower than the rate in the late 1970s, when there were apparently fewer discharge cases per election.

Similarly, the linkage between the number of reinstatees and the union success rate in a given period is placed in question by the experience soon after the NLRA's passage. At that time, there was a concurrence of a large number of reinstatement offers to employees and a high union success rate in NLRB elections. ${ }^{146}$ That earlier experience, together with the data in Table 7, underscores doubts about the causal link between discriminatory discharges during election campaigns and union success rates.

\footnotetext{
${ }^{145}$ The latter percentage follows from Professor Weiler's assertion that one in twenty supporters was discharged during NLRB election campaigns and the GAO's finding that an average of 2.2 employees were covered by complaints that the employer had discriminatorily discharged an employee(s) during organizational campaigns. To arrive at that percentage, we divided Weiler's estimate of the number of employees discharged during organizational drives in $1980(10,833)$ by the estimated number of discharges per case arising in that setting (2.2). See note 136. We then divided that quotient, 4,560 cases, by the number of collective bargaining elections in 1980 , yielding 0.63 , the proportion of elections involving a discriminatory discharge. See 45 NLRB Annual Reports 249, Table 4, and 264, Table 11A (1980).

148 See Miller, An Administrative Appraisal at 163, Table 17 (cited in note 48), showing the approximate number of employees offered reinstatment in the years in question. That number (and the union success rate in collective bargaining elections) was 59,398 (77 percent) in 1939; 37,514 (77 percent) in 1940; 47,902 (94 percent) in 1941; 40,388 (86 percent) in 1942; and 8,361 (86 percent) in 1943. See 4-8 NLRB Annual Reports (1939-43). Granted, those early years under the Act were extraordinary: the NLRA gave a ringing endorsement to unionization as a counterpoise to employer combination and as an anti-depression measure. Employers challenged the Act as unconstitutional; the Great Depression inspired or deepened anti-capitalist attitudes; the $\mathrm{CIO}$ organized the mass production industries; and the AFL and CIO divided on a number of issues. See Harry A. Millis and Emily Clark Brown, From the Wagner Act to Taft-Hartley 34 (Chicago, 1950). Despite its extraordinary backdrop, that early experience casts further doubt on a causal relationship between reinstatement offers and the outcomes of NLRB elections.
} 
More importantly, other NLRB data suggest that even the estimates in Table 7 may overstate the frequency of discriminatory discharges during organizational drives. Those data concern the frequency of unfair labor practice settlements, union objections to election conduct, and recent studies of the incidence of substantive $\S 8(a)(3)$ allegations in connection with NLRB elections. The significance of those data is developed below.

NLRB statistics on the disposition of ULP cases show that most charges leading to reinstatement offers have been settled not only without a Board adjudication but also without great delay. In 1980 , of the cases leading to a reinstatement offer, 72 percent were settled informally by the parties before the issuance of a complaint against the employer. ${ }^{147}$ In 1980 , the NLRB reported that the median time between the filing of a charge and a settlement or adjustment was only 33 days. ${ }^{148}$ Furthermore, settlements including a reinstatement offer have comprised an increasing percentage of reinstatement cases. ${ }^{149}$ Consequently, the number of instances of intentional discharges as part of a strategy of delay has arguably been quite small, involving perhaps three percent of organizational campaigns. ${ }^{150}$

Another indication that discriminatory discharges during organizational drives may be even less frequent than suggested by Table 7 appears in the NLRB's statistics on union objections to election conduct. Those statistics show that in the 1970s and 1980 s, compared to the 1960 s, there was a modest decrease in the number of objections unions filed concerning lost elections. ${ }^{151}$ But

147 See 45 NLRB Annual Report 248, Table 4 (1980); Edward B. Miller, Professor Weilers's Funny Figures (unpublished speech) (on file with U Chi L Rev).

${ }^{148}$ See Comparison of Median Time (Days) Elapsed in Processing Cases (cited in note 49). The median time before a complaint is issued or a charge is settled may, of course, be longer for a \$ 8(a)(3) allegation. Id.

${ }^{148}$ The percentage of cases leading to reinstatement offers resulting from settlements, as distinguished from Board orders, rose from 69 percent in the late 1960 s to $^{\prime} 78$ percent in the 1980s. 29-53 NLRB Annual Reports Table 4 (1964-88).

${ }^{150}$ One way of estimating the number of organizational campaigns involving intentional discharges of union supporters designed to exploit procedural delays is to assume that such violations are eventually adjudicated by the Board. Employers engaging in a strategy of discharge and delay presumably would be much less likely to settle. In fiscal year 1980, the Board adjudicated 985 employer unfair labor practice cases. (A "case" may involve more than one allegation.) The Board ordered employees reinstated in 422 of those cases. See 45 NLRB Annual Report 248, Table 4 (1980). Our sample of Board adjudications indicates that roughly one-half of those orders remedied employer violations during organizational drives. See notes 129-30 and accompanying text. These figures suggest that the Board ordered employees reinstated as a result of discriminatory discharges during 211 (422 times 0.50) or approximately 3 percent of organizational campaigns.

${ }^{181}$ Between 1964 and 1969 (the NLRB first reported such figures in 1964), unions filed 
that decrease would have been unlikely if during the last 20-25 years there had been a surge of employer discrimination designed to avert union election victories. Had employers stepped up such discrimination after an election petition had been filed, ${ }^{152}$ union objections to lost elections would presumably have increased. Hence, the decrease in union objections works against the contention that employers have increasingly sought to frustrate organizational drives through tactics destructive of either laboratory conditions or statutory rights.

Further evidence that our estimates may overstate the incidence of unlawful discharges during organizational campaigns appears in recent studies of NLRB elections by the GAO and by Richard Freeman and Morris Kleiner. The GAO study showed that unions or employees had alleged that employers had violated $\S 8(a)(3)$ in connection with 121 of 368 NLRB elections in $1979 .{ }^{153}$ But the charges connected with 74 of those elections were dismissed or withdrawn, presumably because they lacked merit. ${ }^{154}$ Thus, $\S 8(a)(3)$ charges with merit were filed in connection with 47 , or 13 percent, of those elections. Furthermore, many of those $\S 8(a)(3)$ charges alleged employer discrimination short of discharge. ${ }^{158}$ Consequently, the GAO study implies that the discriminatory discharges occur in less than the 20 percent of election campaigns derived from our sample of Board adjudications. ${ }^{156}$

Freeman and Kleiner's finding points in the same direction. Their sample consisted of charges filed in connection with elections held by the NLRB's Boston and Kansas City Regional Offices between 1979 and 1985. 157 Those data show that 13 percent of 202 NLRB elections involved union allegations of $\S 8(\mathrm{a})(3)$ violations. ${ }^{188}$ One-third of those allegations were, however, either dis-

objections to 27 percent of elections lost, compared to 17 percent of elections lost during the 1970s and 1980s. See 29-53 NLRB Annual Reports Tables 11-11D (1964-88).

132 A losing party may not challenge an election on the basis of discharges that occurred before the filing of an election petition. See The Ideal Electric and Manufacturing Company, 134 NLRB 1275, 1278 (1961).

133 GAO Study at 9-10, Appendix I (cited in note 51).

1 ist Id.

135 See GAO Study at 4-5, Appendix I (cited in note 51).

186 See note 134.

187 We are grateful to Morris Kleiner for providing us with the data used in his study with Richard Freeman. See Richard B. Freeman and Morris M. Kleiner, The Impact of New Unionization on Wages and Working Conditions, $8 \mathrm{~J}$ Labor Econ S8 (1990); Richard B. Freeman and Morris M. Kleiner, Employer Behavior in the Face of Union Organizing Drives, 43 Industrial \& Labor Rel Rev 351 (1990).

${ }^{188}$ Freeman and Kleiner surveyed "firms that had elections with over 20 employees in the potential bargaining unit and obtained on-site interviews with management in 202" 
missed by the Regional Director or withdrawn by the union. ${ }^{188}$ Accordingly, unions may have filed a substantial § 8(a)(3) allegation in less than nine percent of those elections. Moreover, those data do not indicate whether the alleged discrimination involved a discharge or arose before or after certification. Hence, an even smaller percentage of those cases may have involved allegations of unlawful discharges during organizational drives. Although their samples have obvious limitations, the studies by Freeman and Kleiner and by the GAO both suggest that discriminatory discharges during union organizing drives are substantially less frequent than the 63 percent figure that we imputed to Weiler on the basis of our understanding of his methodology. Indeed, those studies indicate that our corresponding 20 percent estimate derived from our sample of Board adjudications may also be excessive.

\section{B. Refusal to Bargain with a Victorious Union}

As indicated above, an employer may block a union from converting an election victory into a first contract by filing pre-certification objections to the election with the NLRB. If the Board overrules such objections, an employer may challenge the subsequent certification and decline to recognize the union, or may purport to recognize it but engage in "sham" bargaining. ${ }^{160}$ Commentators have suggested that employers have increasingly resorted to such expedients in order to avert or delay the bargaining that usually follows a union election victory. ${ }^{161}$ That suggestion is, however, not free from difficulty.

To be sure, it gains some support from the increase in the percentage of elections challenged by employers. ${ }^{162}$ But, as already in-

firms. Unions won 39 percent of those elections. The authors obtained information from 196 firms on whether the union had filed an unfair labor practice charge. Unions filed \$ 8(a)(3) charges in 12 percent of elections lost and 16 percent of elections won. However, it cannot be determined from the survey data whether those charges were filed before or after NLRB certification. See Freeman and Kleiner, 43 Industrial \& Labor Rel Rev at 354-55 (cited in note 157).

${ }^{168}$ The remaining cases were settled or adjudicated.

${ }^{260}$ See notes $105-10$ and accompanying text.

161 See Weiler, 98 Harv L Rev at 357 (cited in note 10). See also William N. Cooke, Union Organizing and Public Policy: Failure to Secure First Contracts 94-98 (W.E. Upjohn Institute for Employment Research, 1985) (reporting on the relationship between unfair labor practice allegations and the chances that newly certified unions would secure a first contract in Indiana (NLRB Region 25) during the late 1970s).

${ }^{182}$ NLRB statistics indicate that employers objected to union or Board conduct in a larger percentage of elections during the 1980s than in the 1960s. Between 1964 and 1969, employers filed objections regarding 7 percent of elections won by unions, compared to employers' objections regarding 10 percent of such elections during the 1970s, and 13 percent 
dicated, ${ }^{163}$ the reasons for that increase are far from clear. Furthermore, other evidence works against the contention that employers increasingly seek to exploit the statutory election procedures in order to frustrate the achievement of a first contract. Thus, in related contexts, employers have not exploited opportunities for delay. Instead, they have consistently agreed to either consent or stipulated elections, with the bargaining unit and other issues resolved by "mutual consent." Employers have been willing to avoid the delay of a hearing on, and initial determination of, such matters by a regional director. ${ }^{164}$

A consent or stipulated election does not bar an objection to an election based on campaign misconduct. When such employer objections are unsuccessful, they may be followed by an employer challenge to a NLRB certification of a union. Such a course of conduct obstructs first contracts for a substantial period. (In a given case, sham bargaining may also cause such obstruction, but, according to our data, does not operate in a significant percentage of cases. Only two decisions in each sample of 1955 and 1980 Board adjudications involved allegations of employer surface bargaining in the period following certification but prior to a first contract.) In short, the key tactic for obstructing first contracts would appear to be employer challenges to certifications and the delays accompanying the resulting ULP proceedings.

There are, however, difficulties in determining whether there has been a significant increase in first contract failures resulting from employer refusals to honor certifications. To our knowledge, pertinent time-series evidence is not available. To be sure, existing estimates of first-contract failure cover 1957-1962, 1970, and 19791985. But those estimates are based on samples derived from substantially different populations. ${ }^{165}$ Consequently, the differential

during the 1980s. See 29-53 NLRB Annual Reports Table 11C (1964-88). See also Cooke, Union Organizing and Public Policy at 55, Table 2-5 (cited in note 161).

${ }^{163}$ See text following note 105.

104 Consent and stipulated elections (as distinguished from Regional Director- or Board-adjudicated elections) accounted for 74 percent of NLRB elections in the 1950s; 77 percent in the 1960s; 81 percent in the 1970s; and 76 percent in the 1980s. See 15-29 NLRB Annual Reports Table 11 (1950-63); 30-53 NLRB Annual Reports Table 11A (1964-88).

According to the NLRB's lexicon, in both "consent" and "stipulated" elections, the parties agree by "mutual consent" to hold an election in a specified unit. In a consent election, final disposition of election challenges or objections is made by the Regional Director, whereas in a stipulated election it is made by the Board. In a "Regional Director" or "Board directed" election, an election is ordered in a specified unit only after a pre-election hearing. See 45 NLRB Annual Report 233-34 (1980).

${ }^{183}$ See Statistical Appendix, Section III, pp 1011-14 for a summary of these estimates and a description of the samples used in each study. 
union success rates may be a function of differences in the populations being compared, as distinguished from differences in employer recalcitrance. It is, accordingly, difficult to determine whether unions have been substantially less successful in converting certification into a first contract in recent years than in the 1950s.

It is also difficult to determine from Board adjudications the rates at which employers have refused to honor NLRB certifications. Extrapolations of such rates from Board adjudications generally overstate the frequency with which such charges arise following certification. For instance, our sample of 1980 Board adjudications shows that approximately 40 percent of $\S 8(\mathrm{a})(5)$ cases involved charges that employers had refused to honor NLRB certifications. But it would be anomalous to apply that percentage to the total number of $\S 8(\mathrm{a})(5)$ charges disposed of by the agency in 1980. That application would suggest that in 1980 there were substantially more charges alleging that employers had refused to honor a certification than there were certifications. ${ }^{166}$ The explanation for that anomaly appears to lie in the fact that charges under $\S 8(a)(5)$ arising from employer challenges to certification are much more likely than other $\S 8(\mathrm{a})(5)$ charges to lead to a complaint and to be upheld by the Board.

Our data, although they do not clearly establish that employer challenges are dilatory ploys, are consistent with that conclusion. The Board, in the unfair labor practice proceedings precipitated by such challenges, almost always reaffirms its representation determinations and upholds the certification. ${ }^{167}$ Furthermore, courts in 76 percent of our sample enforced the Board's resultant bargaining orders. ${ }^{168}$ There is, accordingly, only a small chance that challenges

${ }^{168}$ In 1980 , there were 9,866 cases involving allegations of $\S 8(a)(5)$ violations. If 40 percent of them reflected employers' refusal to honor certifications, 3,946 of such cases would have arisen from that context. By contrast, in 1980, unions won only 3,498 collective bargaining elections. See 45 NLRB Annual Report 243, Table 2, and 280, Table 15B (1980). There is, of course, a difficulty in comparing or linking adjudications of unfair labor practices and certifications of union election victories in the same year. Adjudications in a given year may well deal with conduct occurring in prior years. This difficulty, however, is mitigated by the lack of significant year-to-year variations in the number of certifications in the period involved and by the relatively short delay between an employer's refusal to honor a certification and a resultant remedial Board order. In our 1980 sample, the Board adjudicated such cases with a summary judgment within an average of six months after filing of the charge.

${ }^{16 z}$ In our sample of 1980 adjudications, the Board found that employers charged with violating $\$ 8(a)(5)$ had violated the Act in all but one of the 37 cases involving employer challenges to the Board's representation determinations.

${ }^{188}$ Courts of appeals enforced the Board's order in 16 of the 21 cases in our sample, 
to a certification will be upheld. Given their substantial legal and other costs, including potential employee unrest and reputational damage, such challenges may well be motivated by a desire either to delay bargaining or ultimately to subvert or to avert it by eroding the union's majority support. Nonetheless, the delay motive does not seem to be operative as frequently as some commentators have suggested. ${ }^{169}$ Thus our contextual classifications indicate that in 1980, the Board adjudicated 185 charges alleging that an employer had refused to honor an NLRB certification. ${ }^{170}$ Those cases, however, constituted only five percent of the 3,441 certifications in that year. ${ }^{171}$

\section{Linking Increased Allegations to Increased Violations}

A key premise underlying the rogue employer thesis and assessments of its significance is that the rising number of alleged violations reflects an increase in actual violations. ${ }^{122}$ But the rising tide of litigation throughout our society during the last forty years highlights questions about the relationship between an increase in the number of alleged and actual violations of a law. Several details of the litigation explosion are of special interest here. First, beginning with the 1960s, the number of unfair labor practice charges against unions has risen nearly as fast as charges against employers. ${ }^{173}$ Second, developments under the NLRA generate uncertainty and instability, which breed litigation. Third, Title VII cases involving charges of employment discrimination on grounds

remanded three cases to the NLRB, and denied enforcement in only two cases.

${ }^{160}$ See Weiler, 98 Harv L Rev at 356 (cited in note 10).

170 This estimate rests on the following data. First, there were 37 cases in our sample of 1980 adjudications where the employers had challenged representation determinations underlying an NLRB certification. Second, our random sample consisted of 20 percent of 1980 Board adjudications. Accordingly, we estimated that the Board adjudicated $185(37 \times 5)$ cases where the employer had refused to honor NLRB certification.

${ }^{171}$ That percentage, although small, may encompass situations where, even after the employer's challenges are rejected by the Board or courts, the union finds that employee turnover and the passage of time have eroded its support in the unit despite its election victory.

${ }^{172}$ Weiler, 98 Harv L Rev at 356-57 (cited in note 10); Weiler, 96 Harv L Rev at 177881 (cited in note 8 ).

${ }^{173}$ Between 1950 and 1988, unfair labor practice charges against unions increased from 1,236 to 9,111 (730 percent). That growth rate was faster than the rate of growth in unfair labor practice charges filed against employers. Since the mid 1960s the growth in union unfair labor practice charges has averaged 3.4 percent per year compared with 3.8 percent for the growth in employer unfair labor practice charges. 15-53 NLRB Annual Reports Table 2 (1950-88). 
of race, sex, etc., increased dramatically in the early 1980s. ${ }^{174}$ Finally, the caseload of the entire federal court system has also surged, only in small part because of labor law or employment litigation. ${ }^{175}$ Treating all these forms of litigation as proof of greater lawlessness implies that unions are increasingly violating the NLRA, employers are increasingly discriminating against minorities, and society generally has become less law abiding. All these conclusions may be true, but their truth cannot be established merely by showing that charges of illegality have soared.

There are, moreover, good reasons for doubting each of these conclusions. Competing and plausible explanations have been offered for the surge in litigation in the United States. ${ }^{176}$ These explanations suggest that individuals are more assertive of their formal rights; workers are better informed about their "rights" and the legal process; new rights have been created by legislative and common law development; and incentives to resort to the legal machinery have grown stronger, at least for employees adversely affected by changes in the labor market. These considerations again suggest that the link between increased allegations of employer lawlessness and the declining fortunes of unions is problematic. Plainly, a more definitive appraisal of the rogue employer thesis will require consideration of the increases in allegations of illegality in other contexts, the relationship of such increases to the incidence of actual violations, and the basis, if any, for distinguishing increases in alleged employer violations of the NLRA from increases in charges of illegalities in other contexts.

174 Between 1980 and 1984, the number of employment discrimination suits filed in federal district courts increased by more than 60 percent, after declining slightly between 1976 and 1980. That surge resulted entirely from an increase in individual, as distinguished from class action, suits. EEOC data indicate these suits reflected an increase in the number of individuals complaining of unlawful discharge. Furthermore, the rise in age discrimination complaints did not account for that increase. Between 1980 and 1984, the percentage of such complaints in the EEOC's docket fluctuated around an average of 18.4 percent. See John J. Donohue and Peter Siegelman, The Changing Nature of Employment Discrimination Litigation Figures 3,6, and Table 5 (unpublished working paper, Northwestern University, Apr 1989) (on file with U Chi L Rev).

178 See Paul M. Bator, What is Wrong with the Supreme Court?, 51 U Pitt L Rev 673, 676-77 (1990).

${ }^{178}$ See Richard A. Posner, Federal Courts: Crisis and Reform 62-67 (Harvard, 1985); Marc Galanter, Reading the Landscape of Disputes: What We Know and Don't Know (and Think We Know) about Our Allegedly Contentious and Litigious Society, 31 UCLA L Rev 4 (1983); Michele M. Hoyman and Lamont E. Stallworth, Who Files Suits and Why: An 'Empirical Portrait of the Litigious Worker, 1981 U Ill L Rev 115. 


\section{IMPROVEMENTS IN NLRB Statistics}

We have illustrated how the limitations of the Board's statistics complicate efforts to assess the significance of allegedly increased employer lawlessness and other competing or complementary influences on American deunionization. Furthermore, these limitations presumably contribute to a common failure of commentators to take account of the varied contexts from which $\S 8(\mathrm{a})(3)$ and $\S 8(a)(5)$ charges arise. In particular, commentators have sometimes paid inadequate attention to the number and percentage of such charges arising in contexts far removed from either the organizational campaigns or the post-certification pre-first contract setting. We have also shown that an important reason for these statistical limitations is that the Board generally publishes its data according to the sections of the NLRA implicated by a case, without indicating its industrial relations context. One disadvantage of this method of organization, immediately pertinent here, is its failure to provide easily accessible data regarding either the percentage of alleged and actual $\S 8(\mathrm{a})(3)$ violations in a given year that arose in an organizational context or the percentage of alleged $\S 8(a)(5)$ violations that arose prior to a first contract.

We believe that there are measures that would alleviate the foregoing deficiencies without engendering either great delays in case processing or great expense. In considering such measures, it is useful to distinguish between cases adjudicated by the Board and those involving charges that are settled, dismissed, or withdrawn. In adjudicated unfair labor practice cases, administrative law judges (ALJs) could accompany their opinions with classifications of the industrial relations context out of which a case arose, as well as the section or sections of the Act involved. Table 8 contains tentative suggestions for contextual rubrics for a classification framework to be used by all ALJs. The Board and its staff undoubtedly could refine, supplement, and generally improve those rubrics. ${ }^{177}$ In any event, after the Board reviewed an ALJ's opin-

${ }^{177}$ A quarter of a century ago, Philip Ross castigated the Board for collecting and reporting masses of information of doubtful usefulness, while failing to collect data about "the sources" (presumably the context) of its caseload. See Ross, The Labor Law in Action at 29 (cited in note 30 ). The Board still does not identify the industrial relations context of its docket, except for the relatively few unfair labor practice cases in which it authorizes actions for injunctions under $\S 10(j)$ proceedings. See Quarterly Report of the General Counsel, November 21, 1989, Section 10(j) Authorizations at 1-3. 
ion, a Board member's legal assistant could make appropriate changes in classification, in light of the Board's decision. ${ }^{188}$

\section{TABLE 8}

\section{CLASSIFICATION OF UNFAIR LABOR PRACTICE CHARGES [Industrial Relations Context of Allegations]}

- Concerted activity, no union organizing drive or contract

$\square$ Discharge alleged

- Negotiating with a union lacking majority status

- Organizing drives before and after petition

$\square$ Discharge alleged

$\square$ Other discrimination

- Post-certification/prior to first contract

$\square$ Refusal to bargain: challenge representation determination

Other section 8(a)(5)

Discharge alleged

Strike or lockout

- Established bargaining relationship: existing or expired contracts

Discharge alleged

Other discrimination

Strike or lockout

$\S 8(a)(5)$

Unfair labor practice cases that are settled present special difficulties for a classification system. Scatter-gun allegations are frequent in such cases. Furthermore, the parties generally reach a settlement before the General Counsel has had an opportunity to scrutinize the allegations and issue a complaint, or before Board adjudication refines and resolves the issues raised by a complaint. Consequently, classification of settled cases would be problematic because it would be based on allegations that frequently had not been filtered by the General Counsel or the Board. ${ }^{179}$ Despite these

178 Our proposed classification system may be too broad and may need narrower categories. Furthermore, as under any classification system, subjective appraisals would not be completely eliminated, especially if more than one section of the Act were involved. But our experience with the rubrics of Table 8-even without finer tuning-suggests that, by clarifying the contexts of unfair labor practice charges, they would increase understanding of the Board's business.

179 The Board might be able to use a classification scheme sufficiently simple to enable charging parties to self-report the industrial relations context in which the alleged violation occurred. The classification scheme used by the charging parties could be included on The Charge Against Employer Form, NLRB-501 (GPO, 1984). Although information from the charging party, unreviewed by an NLRB official, would have a greater likelihood of error, such information would be an improvement over the existing situation. Edward B. Miller, former NLRB Chairman, has suggested to the authors that the regional offices, upon issuing a complaint, could code each case for its industrial relations context. That procedure might avoid the need for further case classification by the ALJs or the Board's legal assistants. 
difficulties, even a rough and imperfect classification system would be an improvement over the current system.

A contextually-oriented classification system for both settled and adjudicated cases would increase understanding of the contexts out of which unfair labor practices-actual and alleged-arise. Indeed, a contextual classification system would be helpful in the development and appraisal of reforms, actual or proposed, through legislation, rulemaking, or doctrinal revisions by the Board. To be sure, such proposed "reforms" raise issues of value, ideology, and judgment of consequences, the resolution of which may not be affected by an improved data base. But such issues could be narrowed, illuminated, or resolved more effectively in light of better data on the matrix of violations, actual and alleged, of the NLRA. ${ }^{180}$

It would be natural for the Board to be reluctant to impose additional burdens on its already-hard pressed case-processing staff in order to make its reports more useful to students of the Board's business. Although outsiders are notorious for understating the burdens that their proposals would impose on others, we are doubtful that the adoption of the foregoing proposals would substantially increase the workload of that staff. ${ }^{181}$ Furthermore, gaining a better understanding of the sources of the Board's business would appear to be important enough to justify the added burden. Indeed, a more complete understanding would be useful both to the Board as it reviews and refines its own approaches and to students of the Act as they appraise the Board's work and evaluate recommended statutory changes. ${ }^{182}$

\footnotetext{
180 With respect to representation cases, the regional offices could devise a similar procedure in order to classify such cases. Again, if the Board reviewed a case, a legal assistant could also review the classification used by the regional office.

181 The proposed classification scheme might, of course, indirectly increase the burden on the case-processing staff if that staff were cut in order to fund the hiring of additional statisticians. This scenario seems unlikely, however.

${ }^{182}$ In order to get a better sense of the burdens and benefits, without incurring great costs, the Board could develop a pilot project that would cover cases arising from conduct that occurred in a geographically and industrially diversified group of its regional offices. The Bureau of Labor Statistics might be of help in shaping and evaluating a pilot project along the lines sketched out above. There would appear to be special justification for such collaboration because the Department of Labor (where the BLS is located) is responsible for promoting the welfare of workers, and the Secretary of Labor has broad statutory investigative authority. See 29 USC $\$ \S 551,560$ (1988).
} 


\section{ConCLusion}

The decline of American unions is the result of the complex interaction of a cluster of factors: the economic environment, legal and illegal opposition of employers, the attitudes of employees, and the legal framework. Consequently, it is difficult to assess the independent contribution made to deunionization by each of these factors. Nonetheless, we have concluded that methodological flaws have led some commentators to overestimate the incidence and significance of employer lawlessness. Specifically, the contention that increased employer lawlessness has been a major factor in American deunionization lacks adequate support. Moreover, there is no basis for concluding that the importance of such lawlessness for deunionization comes close to that of structural changes in the U.S. economy. To be sure, structural changes may have increased employers' fears that the increased costs associated with unionization would threaten their firm's profitability or indeed the firm's existence. Such fears may in turn have increased employer opposition-legal and illegal-to unionization. Even so, both legal and empirical considerations indicate that some studies have overstated the significance of employer lawlessness.

We have considered estimates involving the NLRA's prohibition against discrimination and its requirement of good faith bargaining. In connection with the prohibition against "discrimination," our contextual analysis of Board adjudications and settlements demonstrates the considerable significance of employer "discrimination" outside the organizational context. Neglect of this consideration has contributed to excessively high estimates of the incidence of discriminatory discharges during organizational campaigns. Thus, for 1980, we estimated that roughly 1 in 60 union supporters were discharged during such campaigns, in contrast to the 1:20 ratio reported by Professor Weiler and ritualistically repeated by others. Even our lower estimate of the incidence of discriminatory discharges represents a potentially significant disregard by employers of the Act's statutory protections. Our analysis indicates that such illicit activity has been increasing from the 1960 s to the present. Yet we find that the increase does not correlate with the largest decline in union victory rates in NLRB elections in that time frame. Furthermore, even our estimate appears to overstate both the incidence and the rate of increase in discriminatory discharges in the organizational context. A lower estimate is suggested by the Board's statistics on the ratio of elections to petitions, the high and rising fraction of informal settlements leading 
to reinstatement offers, and the stable ratio of union objections to elections lost.

When we turn to the duty to bargain, our data suggest that employers may be denying recognition to certified unions in order to erode union support or, at least, to delay bargaining. Such frustration of the statutory purpose has, of course, disfigured labor relations, from the earliest days of the Act. But serious difficulties surround the contention that there has been a significant increase in such illicit behavior, an increase that has in turn resulted in a substantially smaller percentage of certifications that lead to a first contract. First, the comparisons on which that contention rests have involved samples drawn from substantially different populations. Second, our contextual analysis has indicated that employers challenged only five percent of NLRB certifications. That small percentage suggests that employers' refusal to recognize newly certified unions could not have accounted for much deunionization. Moreover, some of those challenges may have been a good faith effort to vindicate legal rights by the only means that the law provides.

Efforts to assess the significance of discriminatory discharges during organizational drives and refusals to bargain after certification are obstructed by the failure of the Board's statistics to identify the labor relations contexts out of which actual and alleged violations arise. To be sure, such identification would take staff time and call for changes in established procedures. But a contextually-based reporting system promises to increase our understanding of experience under the NLRA, without imposing substantial burdens on the Board's staff.

We should not, however, overlook the limitations of such data in connection with efforts to determine the relationship between union organizational successes and an array of variables that might significantly influence election outcomes. Such variables include, as we have seen, legal and illegal employer opposition; the nature of unions' organizational campaigns; the unions' reputation; the workers' training, skills, and general attitudes toward unions; the workers' perception of their alternative employment opportunities; and the plants' competitiveness. Such a focus on plants is necessary for reliable judgments on whether, for example, apparently discriminatory discharges during organizational campaigns, chilled, served as a rallying point for, or had no substantial impact on organization. Such plant-based studies would be costly and time-consuming and would sometimes generate controversy about method- 
ology rather than consensus about causalities. ${ }^{183}$ Accordingly, we do not suggest that proposals or legislation of new policies would or should wait for such studies. But such periodic and careful ef- forts to assess at the plant level the factors influencing union organizational successes and failures would be useful to those seeking to understand the way the Act works, its connection with the increasingly hard times experienced by unions in the private sector, and the probable contribution of legislative proposals aimed at protecting the rights of employees to choose or reject a union. note 62).

${ }^{183}$ See studies by Getman, Goldberg et al (cited in note 61) and by Dickens (cited in 


\section{Statistical Appendix}

\section{Union Membership AND Union Densities}

Available statistics on union membership and union density in the United States are not comparable across widely separated years. Recent statistics, for example, appear in the Current Population Survey (CPS), a monthly survey of 56,000 U.S. households. That survey reports whether respondents are employed union members and whether their compensation is governed by a collective bargaining agreement. ${ }^{1}$ In contrast, statistics collected prior to 1973 are derived from union membership lists. Although those lists include employed members, they sometimes also include unemployed and retired members. Troy and Sheflin observed that their estimates of the number of union members based on union membership lists were more than 5 percent higher than estimates for the same year derived from the CPS. ${ }^{2}$ Therefore, in order to make Troy and Sheflin's estimates of union membership in the 1950s more nearly comparable with recent CPS based estimates, we multiplied the 1950 s figure by 0.95 . That adjustment is obviously crude but adequate for present purposes. The resulting estimates suggest a significant decline in private sector U.S. union membership: from 14.8 million in 1953 to 10.5 million in 1989.

Our estimate of the decline in union density also required an adjustment to existing statistics. The 1953 figure was derived from Troy and Sheflin's 1953 estimates for the nonagricultural economy: private and public sector (32.5 percent) and public sector (11.6 percent). ${ }^{3}$ Combining those estimates with the fact that the public sector employed 12 percent of the 1953 nonagricultural work force, ${ }^{4}$ we calculated that union density in the private nonagricultural sector as 35 percent for that year.

1 Tabulations of union membership and union density from the CPS are summarized annually in the February issue of Current Wage Developments (published by the U.S. Department of Labor). Statistics covering the 1970s are also summarized in Edward L. Kokkelenberg and Donna R. Sockell, Union Membership in the United States, 1973-1981, 38 Industrial \& Labor Rel Rev 497 (1985).

2 See Troy and Sheflin, U.S. Union Sourcebook at 3-2, 3-3 (cited in main text at note 1).

${ }^{3}$ Id at $3-14$, Table 3.62 .

- See Economic Report of The President 1990 342-43, Table C-43 (cited in main text at note 31 ). 


\section{Samples of Board Adjudications and of Chicago Regional Office Settlements}

The analysis of Board adjudications in Part III draws on random samples of Board decisions in contested employer unfair labor practice cases for 1955 and $1980 .{ }^{5}$ Each sample consisted of 202 decisions. On request, the authors will provide the citations.

We classified each decision (as well as the settled cases from the Chicago regional office) according to the industrial relations context in which the alleged violation(s) occurred. For the purposes of this paper, we used five contexts: (1) concerted activity outside the union context; (2) bargaining with a union lacking majority status; (3) organizational campaigns; (4) post certification but prior to a first contract; and (5) established bargaining relationships. The organizational context included the following settings:

-campaign in progress: period prior to a petition

-campaign in progress: between petition and election

-campaign in progress: period uncertain

-after a formal termination of a campaign

The established bargaining context included the following settings:

- established bargaining relationship: uncertain duration

-established bargaining relationship: 5 years or less

-established bargaining relationship: 5 years or more

- decertification campaign in progress

-bargaining with a successor employer

-representation status established by pre-hire agreement

Thus, panel 1 of Table A presents the industrial relations context of all Board adjudications; panel 2 presents the contexts of adjudications involving $\S 8(\mathrm{a})(3)$ charges; and panel 3 presents the contexts of adjudications involving $\S 8(\mathrm{a})(5)$ charges.

One obvious drawback of our samples is that Board adjudications constitute only a small percentage of all ULP "cases" filed with the Board. ${ }^{6}$ Generally (as in the years we examined), most cases are withdrawn by the charging party, dismissed for lack of merit by the Regional Director (acting for the General Counsel), or

\footnotetext{
5 See 111-14 NLRB (1955); 247-53 NLRB (1980-81).

- According to the NLRB's terminology, " $a$ 'case' is the general term used in referring to a charge or petition filed with the Board." See 45 NLRB Annual Report 232 (1980); 20 NLRB Annual Report 159 (1955). The Board adjudicated 9.6 percent of the 4,459 employer unfair labor practice cases closed in 1955 , compared with 4.4 percent of 29,411 of such cases closed in 1980. See 20 NLRB Annual Report 166-67, Table 8 (1955); 45 NLRB Annual Report 259, Table 8 (1980).
} 
settled by the parties. ${ }^{7}$ Consequently, our samples may not be representative of ULP cases in the Board's total docket. Indeed, our samples may well overrepresent the kinds of cases highlighted by proponents of the rogue employer thesis. Those proponents postulate that employers bent on averting or subverting effective organization employ a strategy of coercion or delay in which they discriminatorily discharge employees during organizational campaigns and refuse to honor NLRB certifications or to engage in good faith negotiations with a newly certified union. Employers charged with such violations would presumably tend to be more resistant to settlement and more inclined to exploit the dilatory potential in the statutory procedures.

There are also difficulties associated with our small random sample of 53 cases from the Chicago Regional Office that were settled in 1985 or 1986 . We examined those cases in order to get a sense of the probable context of charges disposed of without adjudications. ${ }^{8}$ Unfortunately, the information concerning those cases is incomplete and does not reflect a single consistent classification scheme. $^{9}$ The resulting difficulties were compounded by the sample's geographical limitations and its covering of 1985 and 1986 cases instead of the years reflected in our sample of Board adjudications. Because of those deficiencies, our analysis of settled cases is, at best, only suggestive of their general context.

\section{Unions' Success in Securing First Contracts}

We found five studies estimating union success rates in translating NLRB certification into a first contract. Those studies have

7 In fiscal year 1955, 49.2 percent of the employer ULP cases closed were withdrawn by the charging party before a complaint issued; 26.4 percent were dismissed by a Regional Director prior to issuing a complaint; and 11.4 percent were settled by the parties after a complaint issued but before an ALJ hearing. In fiscal year 1980, 30.4 percent of the employer ULP cases closed were withdrawn by the charging party before a complaint issued, 33.2 percent were dismissed by the Regional Director prior to issuing a complaint, and 29.1 percent were settled by the parties after a complaint issued but before an ALJ hearing. See 20 NLRB Annual Report 166-67, Table 8 (1955); 45 NLRB Annual Report 256-57, Table 7 (1980).

We obtained copies of these files through a Freedom of Information Act request and the courteous cooperation of the Board's Chicago Regional Office. Naturally, we would have preferred to have samples of settled cases from 1955 and 1980 , but these files were not available at that office.

- To determine the context and types of charges involved in cases settled, we relied on several documents that typically appeared in the Regional Office's case files. Those documents varied from case to case, but among them were charges against employers, the closed case forms, the complaint and notice of a hearing, the petition for a representation election, and the tally of the ballots. From this information we inferred the types of charges and the context of the cases in our sample. 
been the basis for contentions that that rate declined in recent years. Although the estimates cover different years, they are based on samples of certifications drawn from substantially different populations. For example, the estimate for the late 1950s and early 1960 s is based on a survey of certifications in only six of thirty NLRB Regional Offices. ${ }^{10}$ By contrast, the estimate for 1970 is based on a survey of all AFL-CIO, UAW, and ILWU affiliates."11 That survey excludes certifications involving the Teamsters and other nonaffiliated units, but it includes UAW certifications even though the UAW, like the Teamsters, was then not affiliated with the AFL-CIO. Finally, estimates covering the late 1970s and early 1980 s are based on samples that usually are small and are not representative of the population of NLRB certifications. ${ }^{12}$ Because of those considerations, it is difficult to draw from comparisons among such estimates reliable data on union success rates over time. The findings of those studies and the samples on which they were based are described below.

(1) Ross reported union success rates for 1957-1962.13 In a sample drawn from only six ${ }^{14}$ of thirty NLRB regional offices, he found that 86 percent of the certifications had been followed by a contract with the certified union. In a second and different sample of 575 certifications connected with a "finding or inference" of a $\S 8(a)(5)$ violation, he found that 51 percent of the newly certified unions had secured a first contract. Furthermore, he found that in those situations in the second sample in which the union had secured a contract, 30 percent of the bargaining relationships had ended by 1962.

(2) Prosten reported union success rates for $1970 .{ }^{15}$ Using a sample of 2,656 certifications of AFL-CIO, UAW, and ILWU affiliates, he found that 77.65 percent of the newly certified unions had secured a first contract. He also found that even when unions had done so, 17 percent of the bargaining relationships had ended by 1975. The Teamsters and other non-affiliated unions were excluded

10 See Ross, The Labor Law in Action at 1, 12, 112-13 and 119 (cited in main text at note 30 ). Ross's study had been prompted by suggestions that the enforcement of the duty to bargain under $\S 8(a)(5)$ was ineffective. See id at 4-8.

11 Richard Prosten, The Longest Season: Union Organizing in the Last Decade, a/k/a, How Come One Team Has to Play with Its Shoelaces Tied Together?, Industrial Relations Research Assoc Ser Proc of the 31st Annual Meeting, 240, 246-47 (1978).

12 See Weiler, 98 Harv L Rev at 354 n 5 (cited in main text at note 10).

13 See appendix at note 10 .

14 Ross does not further identify the six NLRB regional offices he examined.

16 See appendix at note 11 . 
from his sample. But the UAW, although then non-affiliated, was included. In any event, Prosten's sample covered only 62 percent of 1970 certifications. ${ }^{16}$

(3) MacDonald reported union success rates for $1979-1981 .{ }^{17}$ Using a sample of 271 certifications of AFL-CIO units with more than 100 employees (or approximately 10 percent of AFL-CIO certifications), ${ }^{18}$ he found that unions had secured a first contract 63 percent of the time. Furthermore, even when unions had done so, he found that 12 percent of such contracts had not been subsequently renewed.

(4) Cooke reported union success rates for $1979-1980 .^{19}$ His study was based on two samples of certifications. The first was a nationwide random sample of 418 certifications of AFL-CIO affiliates. Like Prosten's sample described above, Cooke's first sample excluded certifications involving the Teamsters and other unaffiliated units. Moreover, Cooke's estimates of union success rates were based on only the 140 certifications concerning which he had received responses to his survey of union representatives. His study did not indicate whether that subset of certifications was representative of the entire random sample. For that subset, Cooke found that certified unions had secured a first contract in 72 percent of the cases. Cooke's second sample consisted of 118 certifications from the NLRB's Regional Office in Indianapolis, which included certifications involving the Teamsters and other non-affiliated units. For that sample, Cooke found that 77 percent of the certifications had been followed by a first contract.

(5) Finally, Freeman and Kleiner reported union success rates for 1979-1985 in the NLRB's Boston and Kansas City regional Office. ${ }^{20}$ Using a sample of representation elections in units with more than twenty employees, they found that 67 percent of 79 certifications had been followed by a first contract.

Of all the estimates of union success rates in securing a first contract, the two most nearly comparable are the 77.65 percent reported by Prosten for 1970 and the 72 percent reported by Cooke for 1979-1980. Those two figures were based on samples drawn from similar but not clearly identical populations of certifications.

16 Prosten, The Longest Season at 247 (cited in note 11).

17 See appendix at note 12 .

18 See 45 NLRB Annual Report 286, Table 17 (1980).

19. See Cooke, Union Organizing and Public Policy at 73-76, 84-85 (cited in main text at note 161).

${ }^{20}$ Calculations by authors from sample provided by Morris Kleiner. See main text at notes 157-59 and accompanying text. 
These estimates suggest a slight but not dramatic decline from 1970 to 1980 in the success rates of AFL-CIO affiliates in securing first contracts during that ten-year period. But because of the small size of Cooke's sample, that difference is not statistically significant and could easily have arisen by chance.

TABLE A

THE INDUSTRIAL RELATIONS CONTEXT OF NLRB ADJUDICATIONS

[Percentage of Cases in Each Context]

PANEL 1

The Context of All Adjudications

Context 1955 1980

Nonunion Concerted Activities

Employer-assisted Unions

Organizational Campaigns

Post-election/

Prior to First Agreement

Established Bargaining

Relationships

Number of Adjudications

PANEL 2

The Context of Adjudications of § 8(a)(3) Allegations

Context 1955

Nonunion Concerted Activites

Employer-assisted Unions

4

42

Organizational Campaigns

Post-election/

Prior to First Agreement

6

61

Established Bargaining

Relationships

45

PANEL 3

The Context of Adjudications of $\S 8(\mathrm{a})(5)$ Allegations

Context 1955

1980

Nonunion Concerted Activities

Employer-assisted Unions

Organizational Campaigns

$0 \%$

1

Post-election/

Prior to First Agreement

43

42

Established Bargaining

Relationships

Note: Authors' tabulations were based on random samples of 1955 and 1980 Board adjudications. 